\title{
Naturally Formed Chitinous Skeleton Isolated from the Marine Demosponge Aplysina fistularis as a 3D Scaffold for Tissue Engineering
}

\author{
Tomasz Machałowski ${ }^{1}\left(\mathbb{D}\right.$, Agnieszka Rusak $^{2, *}{ }^{\circledR}$, Benita Wiatrak $^{3,4}{ }^{\circledR}$, Katarzyna Haczkiewicz-Leśniak $^{5}(\mathbb{D}$, \\ Aneta Popiel $^{2}{ }^{2}$, Jakub Jaroszewicz ${ }^{6}$, Andrzej Żak ${ }^{7}{ }^{\circledR}$, Marzenna Podhorska-Okołów ${ }^{5}$ and Teofil Jesionowski ${ }^{1, *(D)}$ \\ 1 Institute of Chemical Technology and Engineering, Faculty of Chemical Technology, \\ Poznan University of Technology, 60-965 Poznan, Poland; tomasz.g.machalowski@doctorate.put.poznan.pl \\ 2 Department of Histology and Embryology, Faculty of Medicine, Wroclaw Medical University, \\ Chalubinskiego 6a, 50-368 Wroclaw, Poland; popielaneta1@gmail.com \\ 3 Department of Pharmacology, Faculty of Medicine, Wroclaw Medical University, J. Mikulicza-Radeckiego 2, \\ 50-345 Wroclaw, Poland; benita.wiatrak@umed.wroc.pl \\ 4 Department of Basic Medical Sciences, Faculty of Pharmacy, Wroclaw Medical University, Borowska 211, \\ 50-556 Wroclaw, Poland \\ 5 Department of Ultrastructural Research, Faculty of Medicine, Wroclaw Medical University, \\ Chalubinskiego 6a, 50-368 Wroclaw, Poland; katarzyna.haczkiewicz@umed.wroc.pl (K.H.-L.); \\ marzenna.podhorska-okolow@umed.wroc.pl (M.P.-O.) \\ check for \\ updates \\ Citation: Machałowski, T.; Rusak, A.; \\ Wiatrak, B.; Haczkiewicz-Leśniak, K.; \\ Popiel, A.; Jaroszewicz, J.; Żak, A.; \\ 6 Faculty of Materials Science and Engineering, Warsaw University of Technology, 02-507 Warsaw, Poland; \\ jakub.jaroszewicz@pw.edu.pl \\ 7 Electron Microscopy Laboratory, Faculty of Mechanical Engineering, \\ Wroclaw University of Science and Technology, Wybrzeze Wyspianskiego 27, 50-370 Wroclaw, Poland; \\ andrzej.zak@pwr.edu.pl \\ * Correspondence: agnieszka.rusak@umed.wroc.pl (A.R.); teofil.jesionowski@put.poznan.pl (T.J.)
} Podhorska-Okołów, M.; Jesionowski, T. Naturally Formed Chitinous Skeleton Isolated from the Marine Demosponge Aplysina fistularis as a 3D Scaffold for Tissue Engineering. Materials 2021, 14, 2992. https:// doi.org/10.3390/ma14112992

Academic Editors: Franz E. Weber and Young-Hag Koh

Received: 30 March 2021

Accepted: 27 May 2021

Published: 1 June 2021

Publisher's Note: MDPI stays neutral with regard to jurisdictional claims in published maps and institutional affiliations.

Copyright: (c) 2021 by the authors. Licensee MDPI, Basel, Switzerland. This article is an open access article distributed under the terms and conditions of the Creative Commons Attribution (CC BY) license (https:// creativecommons.org/licenses/by/ $4.0 /)$.

\begin{abstract}
Tissue engineering (TE) is a field of regenerative medicine that has been experiencing a special boom in recent years. Among various materials used as components of 3D scaffolds, naturally formed chitinous materials seem to be especially attractive because of their abundance, non-toxic and eco-friendly character. In this study, chitinous skeleton isolated from the marine sponge Aplysina fistularis (phylum: Porifera) was used for the first time as a support for the cultivation of murine fibroblasts (Balb/3T3), human dermal fibroblasts (NHDF), human keratinocyte (HaCaT), and human neuronal (SH-SY5Y) cells. Characterization techniques such as ATR FTIR, TGA, and $\mu$ CT, clearly indicate that an interconnected macro-porous, thermostable, pure $\alpha$-chitin scaffold was obtained after alkali-acid treatment of air-dried marine sponge. The biocompatibility of the naturally formed chitin scaffolds was confirmed by cell attachment and proliferation determined by various microscopic methods (e.g., SEM, TEM, digital microscopy) and specific staining. Our observations show that fibroblasts and keratinocytes form clusters on scaffolds that resemble a skin structure, including the occurrence of desmosomes in keratinocyte cells. The results obtained here suggest that the chitinous scaffold from the marine sponge $A$. fistularis is a promising biomaterial for future research about tissues regeneration.
\end{abstract}

Keywords: chitin; scaffolds; fibroblasts; keratinocytes; neurons

\section{Introduction}

Natural polymers (biopolymers) isolated from renewable resources, such as plants, animals, or microorganisms, are attractive propositions of scaffolds substrates [1]. Because of their strong similarity to the extracellular matrix (ECM), the use of such materials may eliminate chronic inflammation, toxicity, or immune system response, commonly recorded through synthetic polymers [2]. Recently, frequently used are natural bioscaffolds based on proteins (e.g., collagen, silk, or gelatin), polysaccharides (e.g., alginate, hyaluronic 
acid, or chitosan), or their combinations [2]. As an example, Baldino et al. described an innovative method of producing alginate-chitosan aerogels for biomedical application through supercritical drying [3]. As observed, chitin has also been intensively developed with respect to biomedical engineering application [4-8]. Thanks to its abundance and extraordinary features, such as biocompatibility and biodegradability, this biopolymer is used in the fields of tissue engineering (TE) $[9,10]$. It should be stated that chitin also present cohesive interaction with blood components, e.g., erythrocytes, IgG, fibrinogen (beneficial for preventing side-effects), and nontoxicity [11]. Nevertheless, for creating an effective scaffold, other parameters must also be provided, such as advantageous 3D geometrical conformation, porosity, wettability, surface roughness, and suitable nano- and micromechanical properties [12]. Moreover, because of its nanoscale fibrous morphology, chitin has been found to be a particularly valuable biological material that accelerates wound healing processes, reduces scarring, and offers antibacterial properties [8]. However, crucial variances exist in the properties, microstructure, and processability of chitins from commercial sources, such as crustaceans or fungi, affecting their application in wound treatment. On the other hand, the use of chitin causes many problems during the creation of 3D scaffolds. Firstly, chitin is insoluble in conventional solvents because of its abundant inter- and intra-sheet hydrogen bonds and crystalline areas [13]. In the literature, we can find only a few solvents for the dissolution of chitin, e.g., hexafluoroisopropyl alcohol (HFIP), a dimethylacetamide (DMA)- $\mathrm{LiCl}$ mixture, $\mathrm{CaCl}_{2}-\mathrm{MeOH}$ mixture, phosphoric acid, or ionic liquids [14]. Secondly, commercial chitin (from crustaceans and fungi) is obtained as granules, flakes, sheets, or powder, not as the two- or three-dimensional scaffolds required for TE applications [15]. Thus, to avoid costly processing, there is an urgent need to seek naturally formed chitinous constructs. Recently, two key routes of scaffold fabrication have been developed. The first involves the production of matrices with previously designed three-dimensional architecture, e.g., by 3D printing [16-19], macro-porous hydrogels synthesis [20-22], or electrospinning [23,24]. The second uses renewable decellularized natural sources of prefabricated scaffolds in their original shape, e.g., autogenic or allogenic ECM [25-27], skeletons with proper architecture [28,29] or plant-based structure [30].

Marine sponges are a remarkable donors of renewable biological materials [28,31]. Especially Verongida (Porifera) in particular was established as a good potential source of bioactive compounds (e.g., aeroplysinin-1 or isofistularin-3) [4,32,33] and chitinous skeletons [34-38]. Moreover, the possibility of underwater sponge farming makes them even more attractive [4]. The first discovery of chitinous skeletons in the marine sponge was in 2007 [39]. These investigations were fascinating from an evolutionary perspective, particularly because they indicated that chitin appeared several hundred million years before those in arthropod skeletons [28]. The fibrous skeletons are made of $\alpha$-chitin, which forms a biocomposite with inorganic salts (calcium- and silica-based) and bromotyrosines. In nature, such constructs are essential for a sponge's mechanical rigidity and for chemical defense against predators [29]. The purified chitinous scaffold obtained after decellularization and demineralization processes has been recognized as a unique microenvironment for cells. As previously described, such constructs have promoted cell and metabolite migration in the cultivation of human mesenchymal stromal cells (hMSCs) [40-42] and cardiomyocytes $[4,34]$. It should be stated that to compare with other "chitin sources", only sponges create a tube-like, interconnected, macro-porous, and structurally organized 3D chitinous matrix. Thus, after well-conducted isolation, a "ready to use" product could be obtained. Moreover, the ability to cultivate sponges under marine farming conditions makes this material especially attractive to compare with other natural and synthetic substrates. Inspired by the above findings, we attempted to use naturally formed chitinous scaffolds from $A$. fistularis marine sponge, which have the appropriate shape, size, and porosity for structural support in cell cultivation. The cultures were lines of murine fibroblasts (Balb/3T3), human fibroblasts (NHDF), human keratinocytes (HaCaT), and neural cells (SH-SY5Y). The cytotoxicity effect, cell distribution, and adhesion were assessed. 
When choosing a material to fill, e.g., bone damage, it is important that the material also provides an appropriate environment for the surrounding nerves. In the case of damage to peripheral nerves, bioactivity and biocompatibility with respect to their regeneration and the correct direction of axonal growth was demonstrated. The obtained results show that chitin-based scaffolds of poriferan origin are promising materials for future tissue engineering applications, particularly as artificial skin or dressing materials.

\section{Materials and Methods}

\subsection{Preparation of Chitinous Scaffolds}

Chitin-based scaffolds were isolated by chemical treatment of air-dried A. fistularis sponge skeleton, with a total isolation time of around 5 days (see Figure 1 ). At the first step, fragments of sponge skeleton were submerged in deionized water for $6 \mathrm{~h}$ to dispose of water-soluble impurities. The skeletons were then immersed in $2.5 \mathrm{M}$ sodium hydroxide solution for $48 \mathrm{~h}$ for decellularization and deproteinization at $36^{\circ} \mathrm{C}$. The $3 \mathrm{D}$ scaffolds were neutralized with deionized water and treated for $4-5 \mathrm{~h}$ with $20 \%$ acetic acid as a demineralization agent. At the pre-final stage, $2.5 \mathrm{M} \mathrm{NaOH}$ solution was again used at the same conditions until pure chitin was isolated. Finally, colorless tubular chitin scaffolds were neutralized with distilled water and then kept in $70 \%$ ethanol at $4{ }^{\circ} \mathrm{C}$.

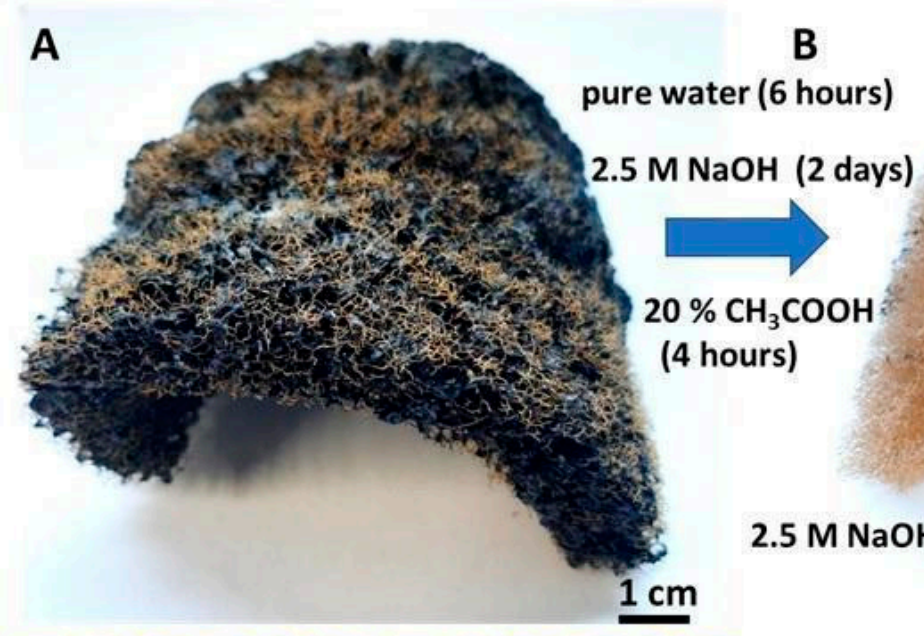

\section{B}

$2.5 \mathrm{M} \mathrm{NaOH}$ ( 2 2 days)
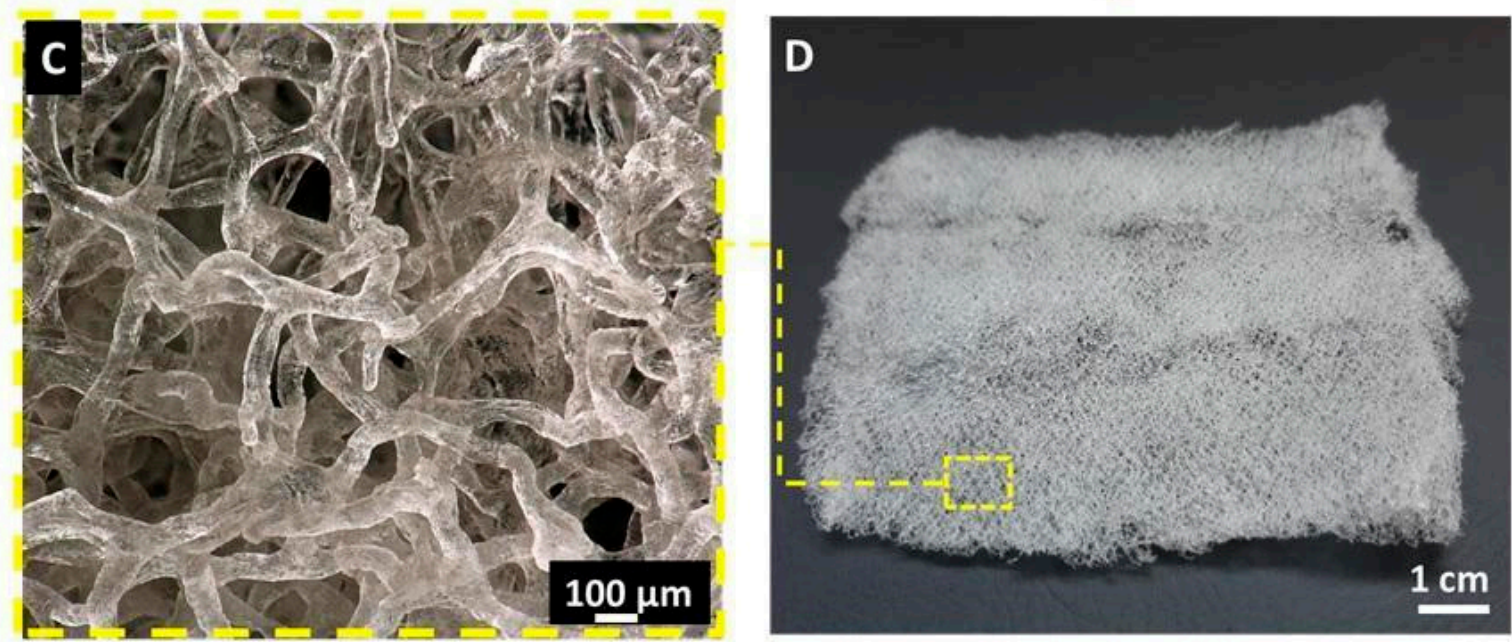

Figure 1. (A) Dried fragment of A. fistularis marine sponge. (B) Chitin-based cell-free skeleton becomes isolated after the first alkali-based treatment. (C,D) Purified 3D chitinous scaffolds which resembles micro-tubular shape and size of natural sponge skeleton. 


\subsection{Chitin Scaffold Sterilization and Preparation}

Pure chitinous scaffolds were sterilized using a high-temperature program for the sterilization of liquids $\left(121^{\circ} \mathrm{C}\right)$. Sterilization was carried out in sterile PBS using a SterilClave autoclave, model 18B, from Cominox (Como, Italy). The sterilized scaffolds were then stored in a $\mathrm{pH}=7.4 \mathrm{PBS}$ solution at $4{ }^{\circ} \mathrm{C}$. Finally, the scaffolds were shifted to a sterile 6-well cell culture plate and incubated into the culture medium with cells.

\subsection{Characterization Techniques}

\subsubsection{Digital Microscopy}

Preparations were visualized using an advanced microscope set consisting of a Keyence VHX-7000 digital optical microscope (Osaka, Japan) and VH-Z20R swing-head zoom lenses (maximal magnification $200 \times$ ).

\subsubsection{Attenuated Total Reflectance-Fourier Transformation Infrared Spectroscopy (ATR FTIR)}

The ATR FTIR infrared spectroscopy technique (attenuated total reflectance) was used for the characterization of the isolated scaffolds and determination of their purity. The presence of characteristic moieties was detected using a VERTEX 70 spectrometer (Bruker, Karlsruhe, Germany). The wide wavenumber range of $4000-400 \mathrm{~cm}^{-1}$ (resolution $0.5 \mathrm{~cm}^{-1}$ ) spectra was recorded. As per the $\alpha$-chitin standard, the well-characterized chitin from the spider Caribena versicolor was used [43]. The degree of acetylation (DA) was calculated as follows-Equation (1) [44]; and the degree of deacetylation (DD) using Equation (2) [45]:

$$
\begin{gathered}
\left.\mathrm{DA} \%=\left[\left(\mathrm{A}_{1654} / \mathrm{A}_{3432}\right) \cdot 100 \%\right)\right] / 1.33 \\
\mathrm{DD} \%=100 \%-\mathrm{DA} \%
\end{gathered}
$$

\subsubsection{Thermogravimetric Analysis (TGA/DTG)}

Qualitative characterization of the isolated chitinous scaffold was performed by thermogravimetric analysis (TGA) using a Jupiter STA 449 F3 analyzer (Netzsch, Selb, Germany). Specimens ( $10 \mathrm{mg}$ ) were inserted on a thermobalance and heated from 30 to $1000{ }^{\circ} \mathrm{C}$ at a heating rate of $10^{\circ} \mathrm{C} / \mathrm{min}$ in a nitrogen atmosphere. Additionally, a DTG curve was plotted to better visualize the process of thermal decomposition.

\subsubsection{Dynamic Mechanical Analysis}

The mechanical (compressive) properties of the isolated scaffolds were investigated by means of monotonic compression tests. Specimens were prepared as cylinders with diameter ca. $9 \mathrm{~mm}$ and height ca. $1 \mathrm{~mm}$. Monotonic compression tests were performed by dynamic mechanical analysis (DMA) using a Q800 instrument (TA Instruments, New Castle, DE, USA). Over the tests, specimens were completely immersed in demineralized water [46]. Samples were preloaded to $0.001 \mathrm{~N}$ and compressed at a constant strain rate of $5 \% /$ minute. The compressive modulus was calculated as the ratio between compressive stress and strain in the linear portion of the curve (at $20 \%$ of total strain), and the area below the stress-strain curve represented specific energy absorbed during deflection of the sponges.

\subsubsection{Microcomputer Tomography $(\mu \mathrm{CT})$}

The $\mu \mathrm{CT}$ image acquisition of the sponge fragment (around $5 \times 5 \times 4 \mathrm{~mm}$ ) was performed in wet conditions. Prior to scanning, samples were partially dehydrated and then dipped into sunflower oil to improve x-ray image contrast. Scanning was performed using a microfocussed X-ray tomographic system (MICRO XCT-400, Xradia-Zeiss, Pleasanton, CA, USA) with the following parameters: $40 \mathrm{kV}$ voltage, $10 \mathrm{~W}$ power, no filter material, $0.16^{\circ}$ rotation step in an angle interval of $184^{\circ}$. The voxel size was $5 \times 5 \times 5 \mu \mathrm{m}^{3}$. The data processing, image analysis and 3D reconstruction of the scanned samples were performed with Avizo Fire (Thermo Fischer Scientific, Hillsboro, OR, USA). 
Porosity was calculated by simple voxel counting in the 3D segmented image. Local pore diameter and fiber thickness were calculated using a model independent sphere filling technique [47]. Outcomes are expressed as mean \pm standard deviation (SD).

\subsubsection{Scanning Electron Microscopy (SEM)}

For SEM examination, the scaffolds with imposed cells of the studied lines were fixed in $2.5 \%$ glutaraldehyde (Serva Electrophoresis, Heidelberg, Germany) diluted in cacodylate buffer (0.2 M, pH 7.4, Serva Electrophoresis). After $1 \mathrm{~h}$, the samples were washed three times in cacodylate buffer for $5 \mathrm{~min}$ at room temperature and postfixed for $1 \mathrm{~h}$ at $4{ }^{\circ} \mathrm{C}$ in $1 \%$ osmium tetroxide (Serva Electrophoresis) diluted in cacodylate buffer. The samples were next bathed three times with cacodylate buffer for $5 \mathrm{~min}$. Dehydration of the samples was performed by increasing concentrations of ethanol (Stanlab, Lublin, Poland) for $15 \mathrm{~min}$ in each solution $(50 \%, 70 \%, 80 \%, 96 \%)$ at $4{ }^{\circ} \mathrm{C}$. Subsequently, the studied cell lines were incubated in absolute alcohol three times for $15 \mathrm{~min}$ at room temperature. Finally, the specimens were transferred to pure acetone, air-dried, and covered with $30 \mathrm{~nm}$ of gold in a high-vacuum sputter coater (Edwards, Burgess Hill, United Kingdom). Observations were taken with a JSM-6610A scanning electron microscope (JEOL, Tokyo, Japan) using $20 \mathrm{kV}$ accelerating voltage and a secondary electron detector, revealing topography contrast.

\subsubsection{Transmission Electron Microscopy (TEM)}

To examine the cell morphology seeded on pure chitin scaffolds, the ultrastructure of the cell lines was checked using the TEM method. Chitin scaffolds with the imposed cells were placed in the cultured media. Next, the medium was discarded, and a 3.6\% glutaraldehyde solution freshly prepared in $0.2 \mathrm{M}$ cacodylate buffer was added ( $25 \mathrm{~min}$, room temperature). In the next step, the fixative was rinsed with $0.1 \mathrm{M}$ cacodylate buffer $(4 \times 15 \mathrm{~min})$ and the samples were left in the same buffer overnight at $4{ }^{\circ} \mathrm{C}$. The cells were then subjected to secondary fixation in $1 \%$ osmium tetroxide diluted in $0.1 \mathrm{M}$ cacodylate buffer ( $1 \mathrm{~h}$, room temperature), followed by washing of the samples in $0.1 \mathrm{M}$ cacodylate buffer ( $3 \times 5 \mathrm{~min}$ ). Next, the material was passed through a series of graded ethyl alcohol solutions (30\%, 50\%, 70\%, $10 \mathrm{~min}$ each, room temperature) and left overnight at $4{ }^{\circ} \mathrm{C}$ in a $70 \%$ solution. The next day, dehydration was continued in solutions of $80 \%$ and $90 \%$ ethanol, then in a mixture of $90 \%$ ethanol $/ 90 \%$ acetone (1:1). Afterward, the cells were passed through a graded series of acetone $(90 \%, 95 \%$, and $100 \%)$. After dehydration, the material was incubated with epoxy resin mixed with pure acetone in a ratio of 1:3 $(20 \mathrm{~min})$, then in mixtures of 1:1 (60 $\mathrm{min})$ and 3:1 (60 $\mathrm{min})$, all at room temperature, and finally refrigerated overnight in pure epoxy resin. Finally, the resin-saturated material was transferred to specimen boxes (flat embedding molds; Pelco, Ted Pella, Redding, CA, USA) and flooded with epoxy resin with a catalyst to facilitate its polymerization. The samples were kept in the oven at $60^{\circ} \mathrm{C}$ for 7 days. Subsequently, epoxy blocks with the embedded scaffolds were cut on a Power Tome XL ultramicrotome (RMC, Tucson, AZ, USA) with a Histo diamond knife (Diatome, Nidau, Switzerland) into semithin sections of $600 \mathrm{~nm}$ thickness. After drying on a heating plate, the sections were stained with a dye solution: toluidine blue (Serva Electrophoresis) and anhydrous sodium carbonate $\mathrm{Na}_{2} \mathrm{CO}_{3}$ (Alchem, Torun, Poland), and closed with a Euparal mounting agent (Roth, Mannheim, Germany). The obtained microscope slides allow careful selection of the studied cell lines for making ultrathin sections (thickness ranging between 60 and $70 \mathrm{~nm}$ ) with the use of an Ultra $45^{\circ}$ diamond knife (Diatome) for TEM documentation. The ultrathin sections were transferred to rhodium-copper grids (Maxta form, 200 mesh, Ted Pella, Redding, CA, USA), contrasted with uranyl acetate and lead citrate trihydrate (Serva Electrophoresis), followed by washing of the grids three times in demineralized water. The grids were stored on a petri dish for $1 \mathrm{~h}$ to dry before being viewed under a JEM-1011 transmission electron microscope (JEOL, Tokyo, Japan) operating at $80 \mathrm{kV}$. Electronograms were collected with the use of the TEM imaging platform iTEM1233 equipped with a Morada Camera (Olympus, Münster, Germany) at magnifications ranging from 3 to $20 \mathrm{~K}$. 


\subsection{Biological Evaluation}

\subsubsection{Cell Lines}

The mouse normal fibroblasts cell line Balb/3T3 (American Type Culture Collection ATCC ${ }^{\circledR}$, Old Town Manassas, VA, USA), the normal human dermal fibroblasts line (NHDF) (Lonza, Basel, Switzerland), the human epidermal keratinocyte line (HaCaT) (DKFZ, Heidelberg, Germany) [48] and the human neuroblastoma cell line (SH-SY5Y) (ATCC ${ }^{\circledR}$ ) were used in the study. The Balb/3T3 and HaCaT lines were cultured with DMEM medium (Lonza) with 10\% foetal bovine serum (FBS) and 1\% L-glutamine with penicillin and streptomycin solution (Sigma-Aldrich ${ }^{\circledR}$, St. Louis, MO, USA). NHDF was grown in FGM $^{\mathrm{TM}}$ Fibroblast Growth Medium BulletKit ${ }^{\mathrm{TM}}$ (Lonza). SH-SY5Y was cultured with F-12 medium (Lonza) supplemented with 10\% FBS (Sigma-Aldrich ${ }^{\circledR}$ ) and 1\% L-glutamine with penicillin and streptomycin solution (Sigma-Aldrich ${ }^{\circledR}$ ). Cell culture was maintained in $5 \% \mathrm{CO}_{2}$ at $37^{\circ} \mathrm{C}$ and $95 \%$ humidity. The cells were assessed twice a week, and the fresh medium was changed or passaged if confluence was approximately $70 \%$.

\subsubsection{Determination of Cytotoxicity}

The scaffolds were evaluated in accordance with the direct method of cytotoxicity evaluation described in ISO 10993-5: 2009 "Biological evaluation of medical devices-Part 5: In vitro cytotoxicity studies" [49,50]. The Balb/3T3 cells were cultured in a 6-well plate $\left(1.0 \times 10^{5}\right.$ cells per well). After $24 \mathrm{~h}$ of culture, a scaffold was immersed in the culture medium and the experiment was carried out for $24 \mathrm{~h}$. Using an Olympus BX51 fluorescence microscope inverted contrast-phase light microscope (Olympus, Tokyo, Japan), morphological changes of cells surrounding the scaffold in the culture were observed. The evaluation was also carried out in a control culture, without contact with the evaluated material.

\subsubsection{Determination of Cell Adhesion}

Mouse fibroblasts (Balb/3T3), normal human dermal fibroblasts (NHDF), and human epidermal keratinocyte $(\mathrm{HaCaT})$ cell cultures were carried out on isolated scaffolds with dimensions of approx. $0.5 \times 0.5 \times 0.4 \mathrm{~cm}$, with cell numbers of $1.0 \times 10^{5}$ (24-h cell culture) and $5.0 \times 10^{4}$ (7-day cell culture) in $3 \mathrm{~mL}$ of complete medium. Cultures were conducted in the complete culture medium described above, in 6-well plates under a controlled gentle rocking platform which allowed verification of the real adhesion of cells on the scaffold surface. Next, the cells were visualized using the following methods.

Crystal Violet staining: Cells were fixed: washed twice with cold PBS (Lonza) and then incubated for $10 \mathrm{~min}$ in cold methanol $\left(-20^{\circ} \mathrm{C}\right)\left(\mathrm{Chempur}^{\circledR}\right.$, Piekary Slaskie, Poland). After that, cells were incubated for $10 \mathrm{~min}$ in a solution of $0.5 \%$ Crystal Violet in $25 \%$ methanol (Sigma-Aldrich ${ }^{\circledR}$ ) [51]. The Crystal Violet was then washed several times in water, and the cell adhesion to the scaffold surfaces was assessed using an Olympus CKX53 inverted contrast-phase microscope.

Neutral Red staining: The medium with cells cultured with scaffolds was removed and a fresh culture medium with $40 \mu \mathrm{g} / \mathrm{mL}$ of Neutral Red (Sigma Aldrich ${ }^{\circledR}$ ) was added [52]. After $3 \mathrm{~h}$ of incubation under standard conditions $\left(37^{\circ} \mathrm{C}, 5 \% \mathrm{CO}_{2}\right)$ the cell adhesion to the scaffold surfaces was assessed using an Olympus CKX53 inverted contrast-phase microscope and an Olympus BX51 fluorescence microscope.

\subsubsection{Experimental Model for Neuronal Cells}

Two types of 12-well plates were used in experiments-plates provided from the producer, and plates with the modified surface of the culture wells with collagen. The modification was carried out using collagen type I solution at a concentration of $0.01 \%$ $(w / v)$ overnight at $4-8{ }^{\circ} \mathrm{C}$. Before use, the plates were exposed to UV light for $30 \mathrm{~min}$ for sterilization. The scaffold was cut into $0.5 \times 0.5 \times 0.4 \mathrm{~cm}$ fragments and then used in experiments in two ways. SH-SY5Y cells were seeded at a density of 50,000 cells/well directly onto the material (chit.1), or the scaffold without cells was immersed into a well with the previously seeded cells (chit.2). For the cells' adherence to the scaffold, 50,000 cells 
were seeded directly onto it in a volume of $100 \mu \mathrm{L}$ medium. After $30 \mathrm{~min}$ of incubation, the solution in the well was diluted to a final volume of $1 \mathrm{~mL}$. Two types of control were used in the experiments. The first control cells were cultured only in complete medium F12 (Compl.) and in the second, in a medium containing retinal acid/NGF (neurite growth factor). Observations and evaluations were carried out at four time points: one day after seeding, and after 3,5, and 9 days of incubation with retinal acid/NGF. The number of cells in the collected medium that adhered to the scaffold and to wells' surface were counted. The SH-SY5Y cells were counted on the three different levels of the scaffold. The study involved four independent experiments under repetitive conditions, each of which included three replicates.

\section{Detection of Apoptosis}

Cell apoptosis was checked using a staining kit provided by Sigma-Aldrich (St. Louis, MO, USA) containing Annexin V conjugated with Fluorescein and propidium iodide. The SH-SY5Y cells were transferred to test tubes and incubated with Annexin V and PI solution in the dark at RT for $20 \mathrm{~min}$. The viability of the culture was assessed by the image-based cytometer Arthur (NanoEnTek, Seoul, Korea) (living, apoptotic and necrotic cells).

Analysis of the Number of Cells on the Scaffold

The scaffold was cut into $0.5 \times 0.5 \times 0.4 \mathrm{~cm}$ fragments and then used in experiments in two ways. SH-SY5Y cells were seeded at a density of $5 \times 10^{4}$ cells/well directly onto the material. For the cells' adherence to the scaffold, $5 \times 10^{4}$ cells were seeded directly onto it in a volume of $100 \mu \mathrm{L}$ medium. After $30 \mathrm{~min}$ of incubation, the solution in a well was diluted to a final volume of $1 \mathrm{~mL}$. Two types of control were used here. The first control cells were cultured only in a complete medium, and the second in a medium containing retinal acid. Observations and evaluations were carried out at four time points: one day after seeding, and after 3,5, and 9 days of incubation with retinal acid. The number of cells adhering to the scaffold and adhering to the wells' surface was counted. The SH-SY5Y cells were counted on three different levels of the scaffold. The study involved four independent experiments under repetitive conditions, each of which included three replicates.

\section{Statistical Analysis}

The obtained results have been analyzed according to generally accepted principles. Initially, the normal distribution was checked using the Shapiro-Wilk test, and equality of variance using Levene's test. The Kruskal-Wallis test and post hoc analysis have been done.

\section{Results and Discussion}

The microstructure of chitin-based scaffold from A. fistularis marine sponge skeleton is represented in Figure 1C,D. As excepted, the typical macro-porous morphology of the sponge structure is visible [53]. The polydisperse nature of the interconnected pore sizes is illustrated in Figure 2, where variations of the colors represent pores of different dimensions. The relationship between colors and interconnected pores size is shown by color calibration bars. Moreover, for more details, the main porosity parameters are given in Table 1.

Table 1. Quantitative data on porosity, pore size, and scaffold fiber thickness distributions and average values, obtained by analysis of $\mu \mathrm{CT}$ data.

\begin{tabular}{ccc}
\hline Porosity (\%) & Average Pore Diameter $(\mu \mathrm{m})$ & Average Fiber Thickness $(\boldsymbol{\mu m})$ \\
\hline 79 & $298( \pm 43)$ & $98( \pm 35)$ \\
\hline
\end{tabular}



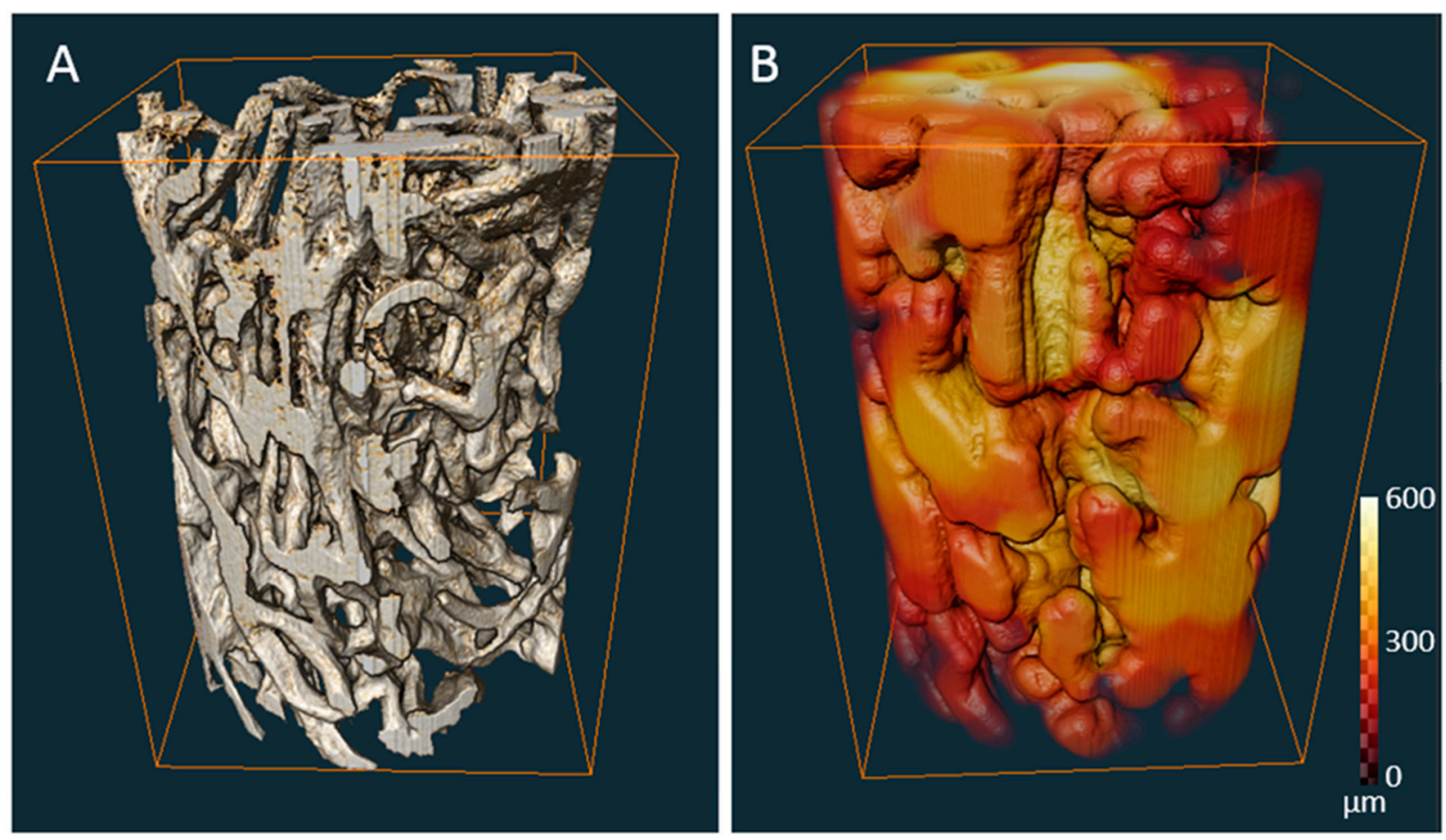

Figure 2. Three-dimensional visualization obtained from $\mu \mathrm{CT}$ analysis of (A) chitinous scaffold structure in wet conditions and (B) colored maps of pore sizes distribution.

Figure 3 shows the FTIR measurements of the pure chitinous skeleton from A. fistularis (grey line) used as a scaffold for cell culture. Based on our calculations (Equations (1) and (2)), the degree of acetylation (DA) was determined as $79 \%$, which is characteristic of chitin isolated by alkali treatment [44]. The degree of deacetylation (DD) was calculated as $21 \%$, which confirms a highly $\mathrm{N}$-acetylated biopolymer [54]. The spectrum includes a split peak at $1654 \mathrm{~cm}^{-1}, 1623 \mathrm{~cm}^{-1}$ corresponding to stretching vibrations of $\mathrm{C}=\mathrm{O}$ bonds (amide I) in chitin [55]. This characteristic band is associated with the $\alpha$-chitin polymorph, and more precisely with stretching vibrations from inter- $(\mathrm{C}=\mathrm{O} \cdots \mathrm{H}-\mathrm{N})$ and intramolecular $\left(\mathrm{C}=\mathrm{O} \cdots \mathrm{HOCH}_{2}\right)$ hydrogen bonding [53]. The existence of $\alpha$-chitin in the skeleton of the $A$. fistularis marine sponge was proved previously [53]. Moreover, the presence of such signals is characteristic of amide II $(v \mathrm{~N}-\mathrm{H}$ and $v \mathrm{C}-\mathrm{N})$ at $1552 \mathrm{~cm}^{-1}$, and amide III $\left(\mathrm{CH}_{2}\right.$ wagging) at $1315 \mathrm{~cm}^{-1}$. This also established the pure $\alpha$-chitin existence $[7,44,56]$. Other bands associated with chitin were observed at $1435 \mathrm{~cm}^{-1}\left(\mathrm{CH}_{2}\right.$ bending and $\mathrm{CH}_{3}$ deformation), $1374 \mathrm{~cm}^{-1}$ ( $\mathrm{CH}$ bending and $\mathrm{CH}_{3}$ symmetric deformation), $1154 \mathrm{~cm}^{-1}$ (asymmetric carbonoxide bridge) [57], $1062 \mathrm{~cm}^{-1}$ (C-O-C stretching), $896 \mathrm{~cm}^{-1}$ (corresponding to glycosidic linkage and $\mathrm{CH}$ stretching vibrations of saccharide rings), and $688 \mathrm{~cm}^{-1}(\mathrm{OH}$ out-of-plane bending) $[44,56,57]$. Compared with the $\alpha$-chitin standard our scaffold did not exhibit any additional signals, which confirms the obtaining of a pure chitinous scaffold.

The TGA graphs shown in Figure 4 present two significant regions. The first lies in a temperature range of $80-110{ }^{\circ} \mathrm{C}$, caused by the loss of water molecules physically and chemically bound to the material [58]. The quantity of water lost is estimated at around $6 \%$. The second important mass loss lies in the temperature range $200-400{ }^{\circ} \mathrm{C}$ and correspond to the thermal and oxidative decomposition of the $\alpha$-chitin [56]. The highest rate of decomposition, represented by the maximum peak of the DTG curve, about $8 \% / \mathrm{min}$ for pure chitin, occurs at a temperature of about $330^{\circ} \mathrm{C}$. The characteristic TGA curve may indicate the presence of a pure chitinous scaffold. 

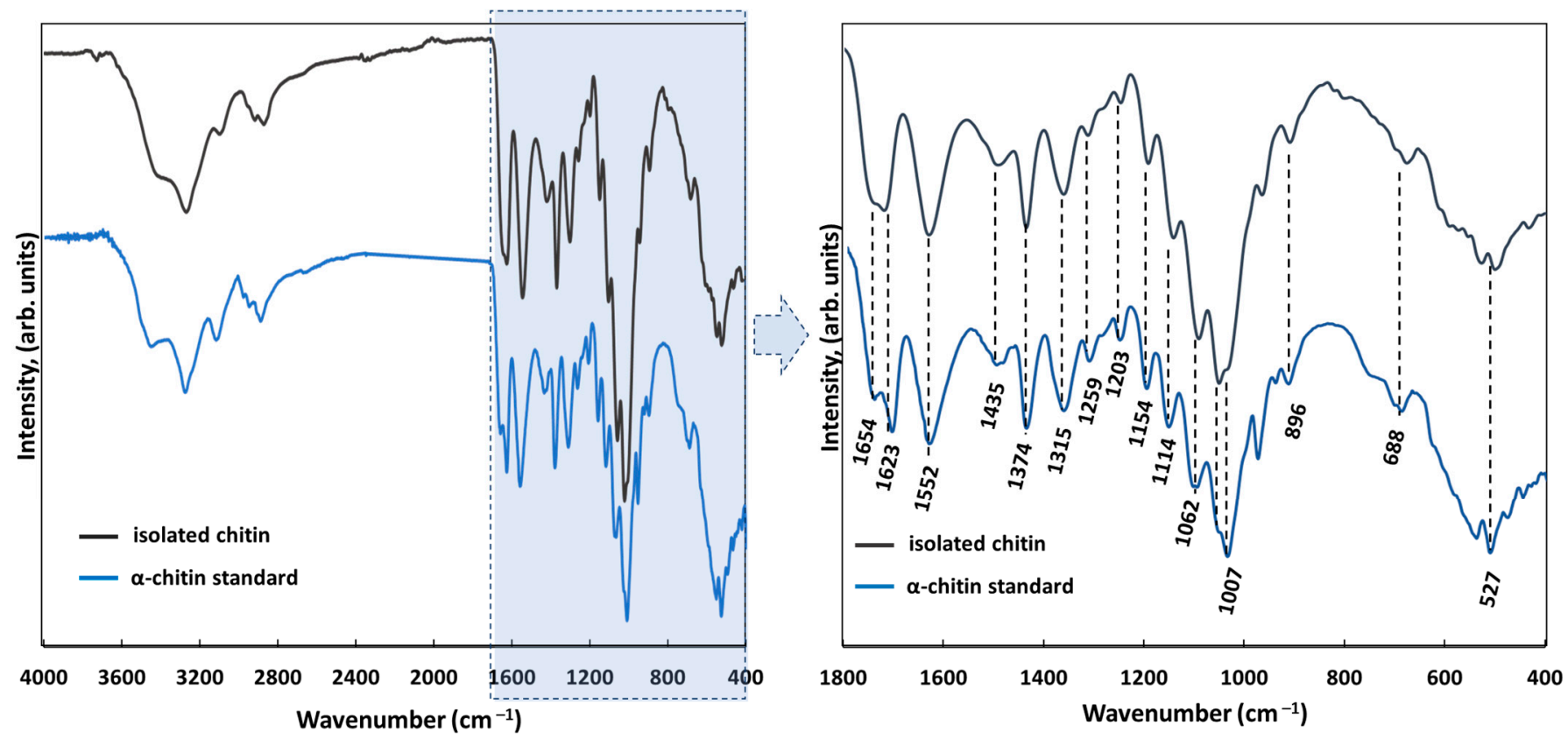

Figure 3. FTIR spectrum of chitin-based scaffold (grey line) obtained from A. fistularis sponge as well as an $\alpha$-chitin standard (blue line) isolated from the Caribena versicolor spider's molt cuticle, fully characterized previously [43].

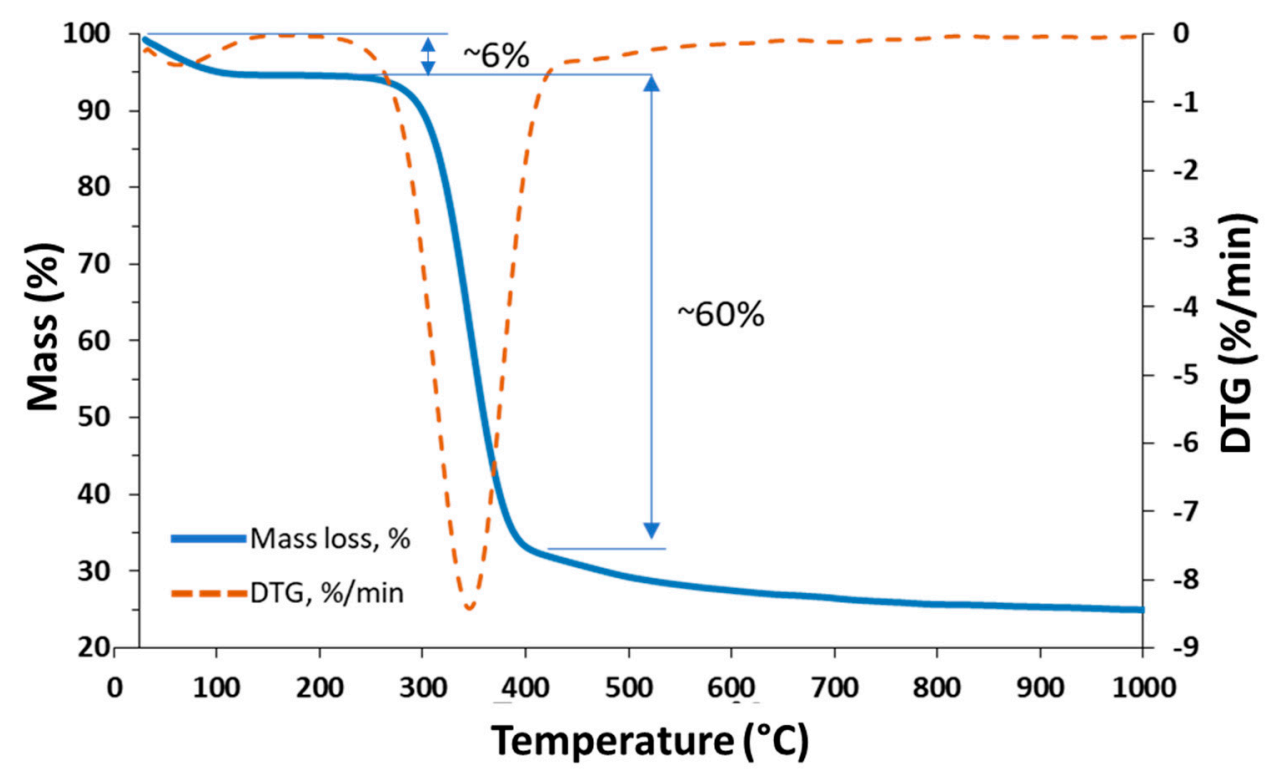

Figure 4. TGA/DTG curve of pure chitinous scaffold isolated from A. fistularis marine sponge.

The macro-scale mechanical properties of the $\alpha$-chitin scaffolds isolated from A. fistularis marine sponge were identified here. The Young's modulus of native soft tissues and organs has been found to range from $0.1 \mathrm{kPa}$ to $1 \mathrm{MPa}$, depending on the function and tissue type [59,60]. For example, in work present by Přádný et al. [22], authors mentioned, that collagenous layers from biological tissues reflect Young's modulus range, $<1 \mathrm{kPa}$ (nerve tissue), approximately $10 \mathrm{kPa}$ (muscle tissue), and about $100 \mathrm{kPa}$ (hard tissue). Thus, the mechanical properties of scaffolds are among the most important parameters limiting cellular behavior [59]. As reported by Breuls et al., stiffness values for PA hydrogel should possesses, for example, $\sim 0.5 \mathrm{kPa}$ (brain tissue), $\sim 10 \mathrm{kPa}$ (muscle tissue), and $>30 \mathrm{kPa}$ (pre-mineralized bone) [61]. Previously, polyacrylamide (PA) hydrogel acting as a cell culture support $(\sim 1 \mathrm{kPa})$ has been successfully used for human fibroblast cultivation. However, Intini et al. used a chitosan-containing 3D-printed scaffold with Young's modulus 
$\sim 105 \mathrm{kPa}$ for an in vitro experiment with human skin cells [62]. Figure 5 illustrates the stress-strain curves obtained for scaffolds in a monotonic compressive test. The curves exhibit a non-linear trend without exact yielding points. The low stiffness in the first stage of test growth is very intensive in the second stage, similarly to natural extracellular matrices (ECMs) [63]. The overall apparent compressive modulus was estimated here as $\sim 0.5 \mathrm{kPa}$. However, the stress is imposed on few fibers within the sample cross-sectional area and could be disturbed by water flow out of the structure. Modulus is a product of proportionality between acting stress and strain, while stress is expressed as force per area. In this case, the apparent modulus of the structure is much lower than the modulus of the fiber bulk. Thus, in future research, the modulus of the fiber bulk should be determined for better understanding.

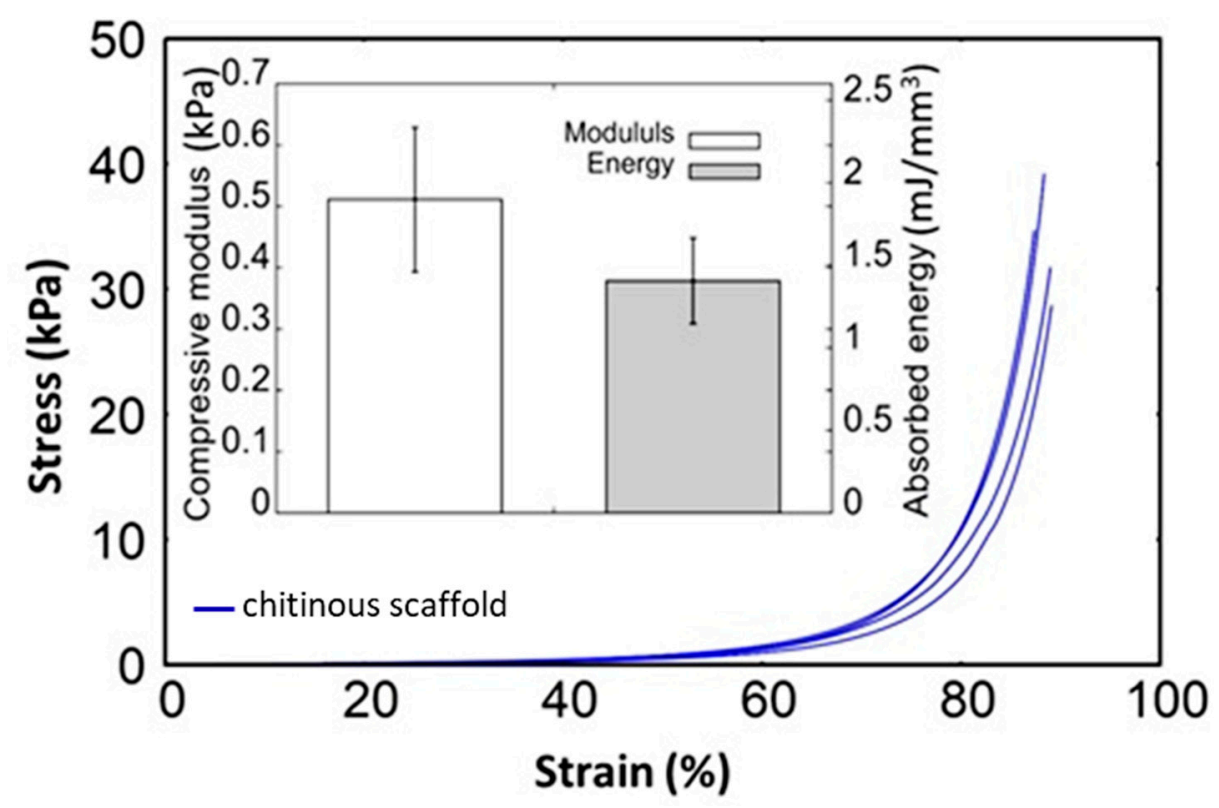

Figure 5. Compression stress-strain response for pure chitin-based scaffolds obtained by alkali-acid based treatment of $A$. fistualris skeleton.

Cytotoxicity studies of chitin scaffolds did not show any changes in Balb/3T3 cell morphology after $24 \mathrm{~h}$ incubation under and near the scaffolds, which indicates the material's lack of cytotoxicity. The morphology of cells incubated with chitin scaffolds was indistinguishable from that of the control cell culture without contact with this material (see Figure 6).

Crystal Violet staining showed single cells of Balb/3T3, NHDF and HaCaT adhering to the chitin scaffold surface after $24 \mathrm{~h}$ of the experiment. However, after 7 days of incubation, clusters of cells were observed on the chitin scaffold surface, which indicates cell adhesion on the investigated material (Figure 7). Interestingly, cell spreading was observed only after 7 days of incubation (see yellow arrows in Figure 7D). Nevertheless, the round morphology adopted by cells and limited spreading may be associated with the very soft mechanical properties of the obtained constructs and low protein adsorption [61]. In this context, the natural forces generated by the adhering cells probably exceeded the physical interactions between the adsorbed proteins and the chitin matrix. Thus, cells proliferation has been determined in respect to neuronal cells below. 


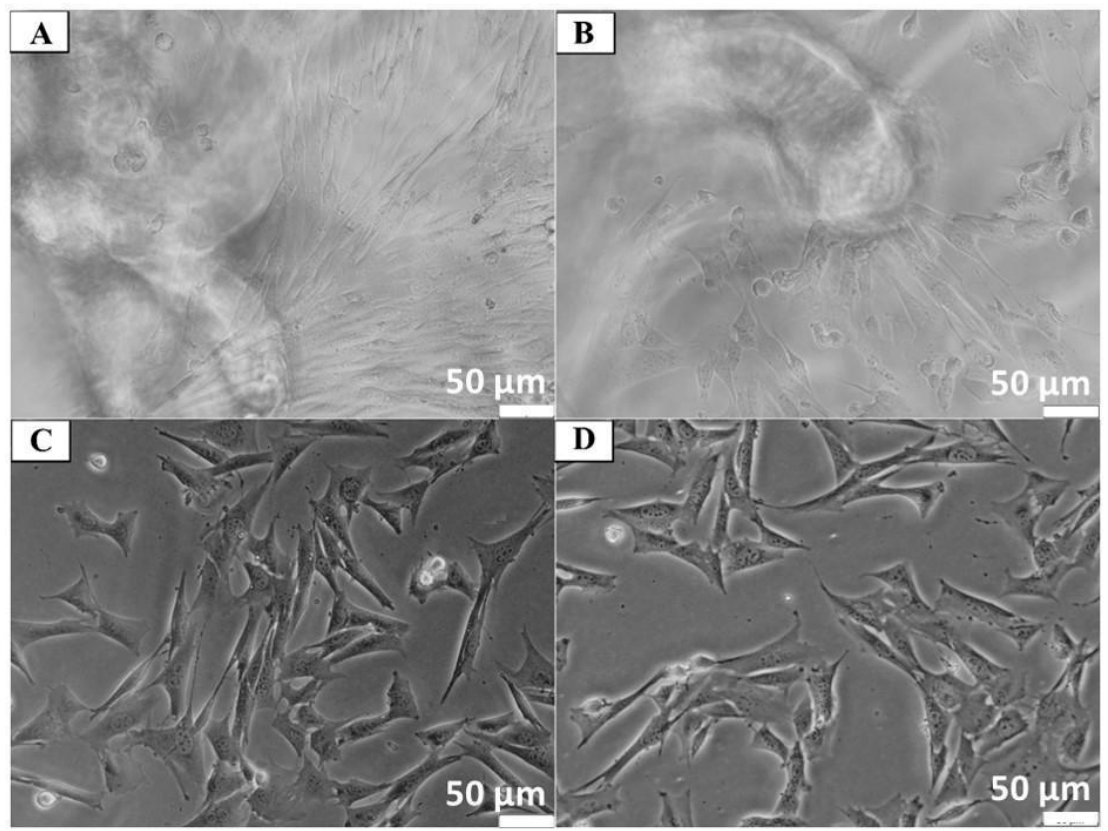

Figure 6. Evaluation of cytotoxicity of chitin scaffolds after $24 \mathrm{~h}$ contact with Balb/3T3 cell culture. (A) Cells under the scaffold; (B) near the scaffold; (C) at a distance from the scaffold; (D) control culture.

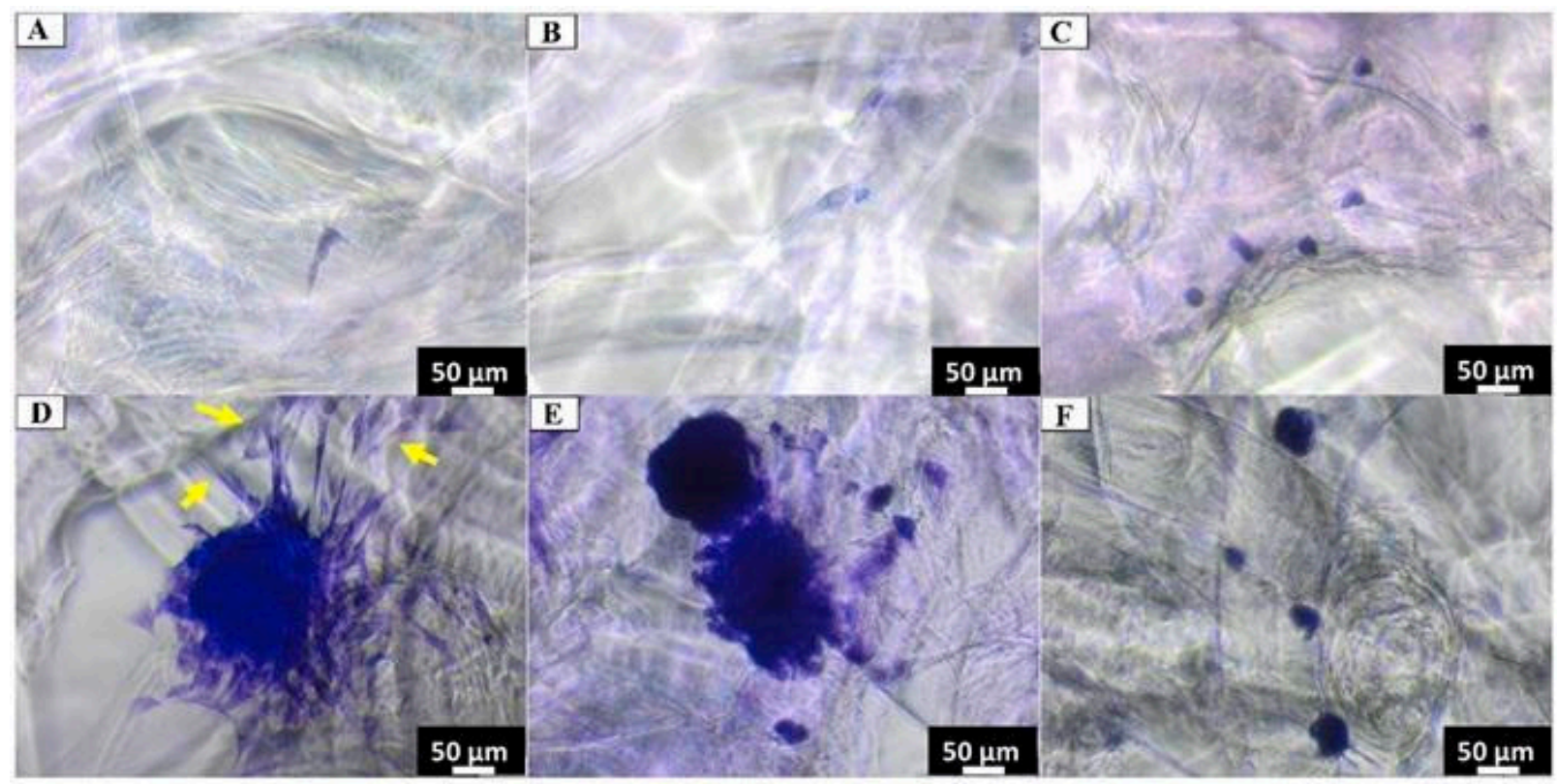

Figure 7. Cell cultures on chitin scaffold surface visualized with Crystal Violet staining (A-C) after incubation for $24 \mathrm{~h}$ and (D-F) for 7 days. (A,D)—Balb/3T3; (B,E)—NHDF; (C,F)—HaCaT.

To investigate the biocompatibility of the of the 3D chitin scaffold on the different types of cells involved in wound healing (keratinocytes and fibroblasts), neutral red livecell staining was performed. Our results show the single cells of Balb/3T3, NHDF, and $\mathrm{HaCaT}$ adhering to the chitin scaffold surface after $24 \mathrm{~h}$ of incubation. In addition, after 7 days of the experiment, clusters of cells were visible on the chitin scaffold surface under inverse contrast-phase and fluorescence microscopes (see Supplementary Materials Figures S1 and S2).

To further characterize the Balb/3T3, NHDF, and HaCaT of cells attached to the chitin scaffold, scanning electron microscope images were obtained. Visualization of cell behavior on the chitin scaffolds after $24 \mathrm{~h}$ of incubation on the material surface confirmed the previ- 
ous results. Analysis of cells cultured for 7 days showed clusters of cells on the chitin scaffold surface, which suggests that the cells adhere and proliferate on that surface (Figure 8). Similar cell behavior has been observed previously on a poly(e-caprolactone)/chitosan scaffold [64]. For a comparison with a chitinous scaffold surface before cell seeding, see Figure S3.
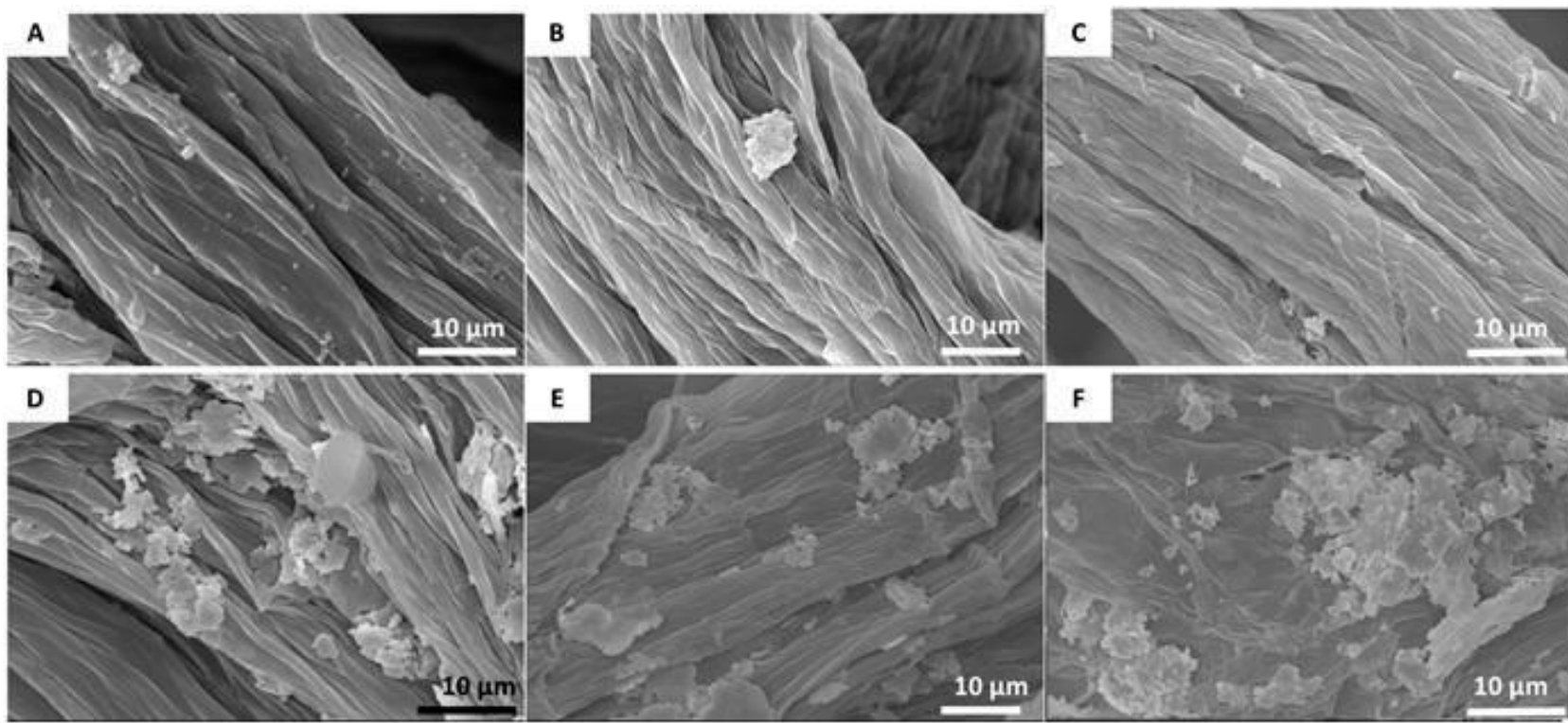

\section{E}
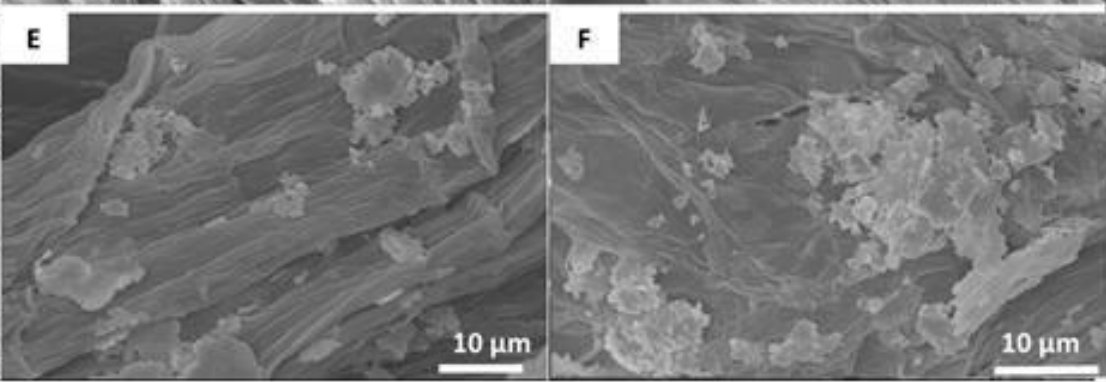

Figure 8. SEM photographs showing cell adhesion on a chitin scaffold surface. Cells after $24 \mathrm{~h}$ and 7 days of culture have been shown. (A,D)-Balb/3T3; (B,E)-NHDF; (C,F)-HaCaT. A rise in the number of cells is visible after 7 days compared to the $24 \mathrm{~h}$ cell cultures.

The ultrastructure of keratinocytes and fibroblasts was evaluated after enhancing the contrast (counterstaining) of the cell membranes with uranyl acetate and lead citrate, respectively. Both single cells and clusters of cells were visible directly on the surface of the chitin scaffolds or in their vicinity (Figure 9A-C). Keratinocytes were oval or spindleshaped, with an elongated euchromatic nucleus. The nuclei contained one to three distinct and compact nucleoli and had an irregular nuclear envelope. The cytoplasm was rich in lipid droplets, vacuoles, polyribosomes, scattered sacs of rough endoplasmic reticulum (RER), and intermediate filaments. Elongated or round mitochondria contained lamellar cristae (Figure 10A,B). Furthermore, keratinocytes formed many layers of cells interconnected with each other by well-developed desmosomes (Figure 10C,D). The ultrastructure of the fibroblasts was as follows, the cells contained conspicuous and well-developed Golgi apparatus, abundant vesicles, and multivesicular bodies. Furthermore, the cell membrane of the fibroblasts formed short and stubby microvilli. In comparison to keratinocytes, the cytoplasm contained many vacuoles and more abundant sacs of RER. Round or elongated mitochondria featured lamellar cristae. The oval euchromatic nuclei had indentations in the nuclear envelope and prominent reticular nucleoli (Figure S4A-D). The ultrastructure of both cells, keratinocytes and fibroblasts, was excellently preserved and did not show features of degeneration, which additionally support our results about nontoxicity and biocompatibility of the chitin scaffolds. There were no signs of any of the well-known types of cell death, like chromatin condensation and fragmentation, shrinkage of the cells, plasma membrane rupture or blebbing, cytoplasm swelling, or organelle degradation $[65,66]$. Moreover, we did not observe any ultrastructural changes in mitochondrial cristae (remodeling or rupture) or in the outer mitochondrial membrane, as well as mitochondrial edema, which would indicate the participation of these organelles in the induction of apoptosis or necrosis [66]. Changes in mitochondrial ultrastructure faithfully reflect the cell's response to stimuli inducing cell death, such as mitochondrial fission and condensation of 
cristae $[65,66]$. Our results can indicate that the presented biomaterial forms a favorable environment for the cells. It may also signal future applications of chitinous scaffolds because keratinocytes are the major cell type in the skin. Furthermore, as estimated, keratinocytes play key roles in wound repair as structural and immune functional factors [67]. Nevertheless, it was most important that we prove the non-toxicity of scaffold and determine the proliferation of the neuronal cells line.
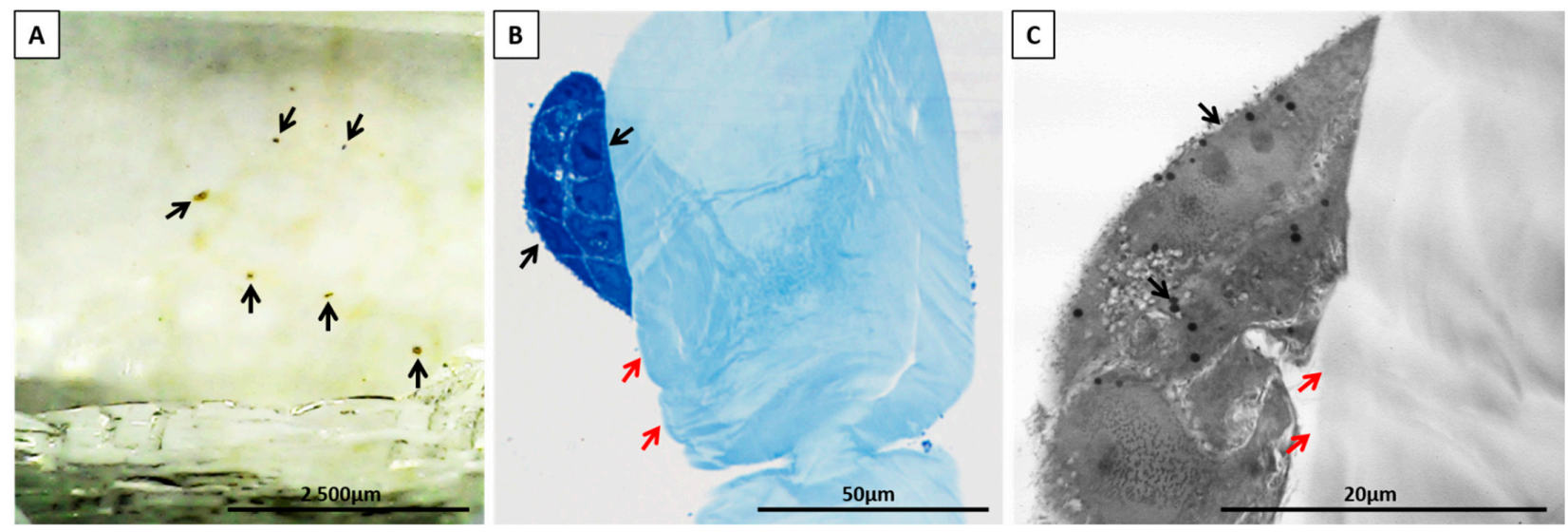

Figure 9. Clusters of HaCaT cells (black arrows) after osmium tetroxide post-fixation (A), toluidine blue staining (B), and counterstaining with the heavy metal salts $(\mathbf{C})$ are attached to the chitin scaffolds (red arrows). A—epoxy resin block; B-semithin section; C-ultrathin section.
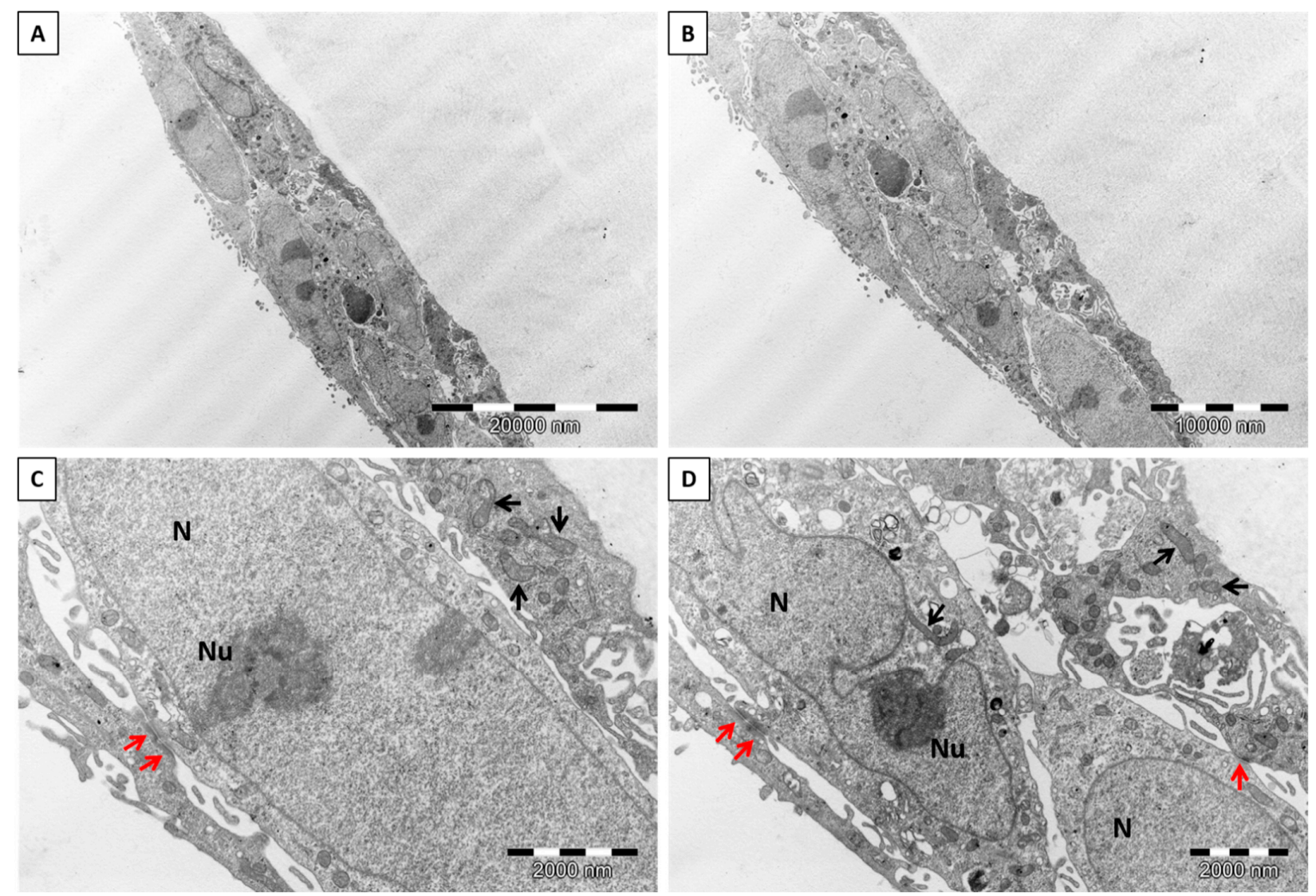

Figure 10. Representative electron microphotographs of HaCaT cell morphology. Nuclei without signs of death are conspicuous, and the well-preserved ultrastructure of organelles is visible. $\mathrm{N}$-nucleus, $\mathrm{Nu}$-nucleolus, black arrowsmitochondria, red arrows—desmosomes. Magnification: (A)—3000×; (B)—4000×;(C,D)—20,000×. 
The Hoechst 33258 staining showed single SH-SY5Y cells adhering to the chitin scaffold surface after $24 \mathrm{~h}$ of incubation (Figure 11A). After 5 days of incubation, clusters of cells were observed. These cells grew on top of each other to form a sphere and did not spread over the entire surface of the scaffold, creating a monolayer (Figure 11B). However, after 9 days of incubation, clusters of cells were again observed on the chitin scaffold surface, but these cells also migrated to the surface of the well. After migration of SH-SY5Y cells onto the surface of wells, the cells had normal morphology, and were of polygonal shape with small neurites (Figure 11C). The performed cell apoptosis test showed that the number of apoptotic and necrotic cells did not exceed $7 \%$ in total, for all tested cases.
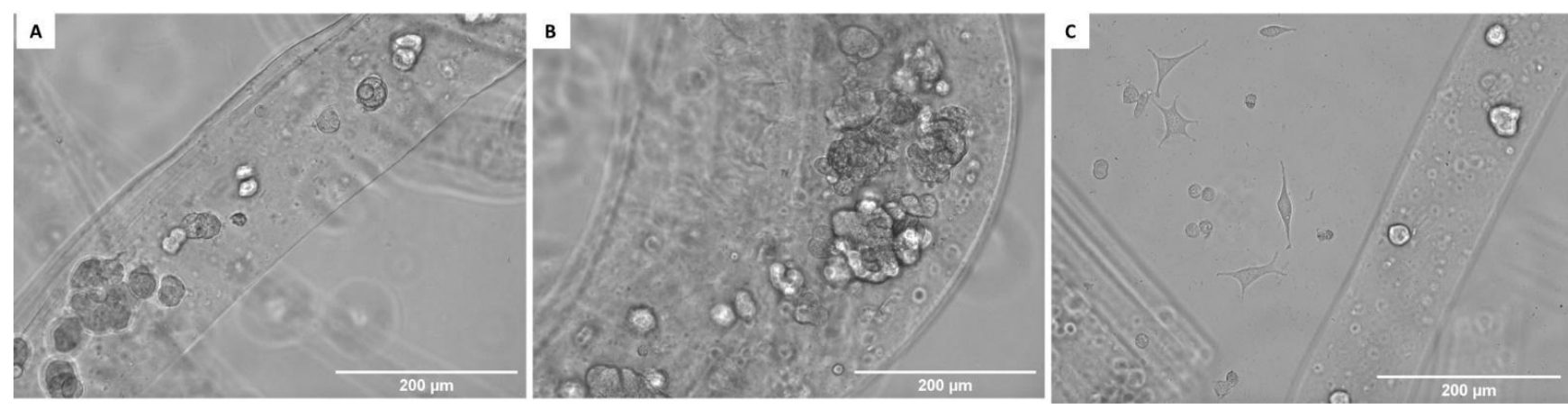

Figure 11. (A-C) Neuronal cells SH-SY5Y adhering to chitin scaffolds isolated from A. fistualris marine sponge skeleton. Scale bar $200 \mu \mathrm{m}$.

The analysis of the number of cells in the collected medium and on the surface of the material was compared to the results obtained for the culture carried out on the modified and unmodified plates. The study was carried out at four time points-in the 1st, 3rd, 5 th, and 9th day of breeding. The number of cells in the collected complete medium and medium containing retinal acid is shown in Figure S5, taking into account the culture on modified and unmodified plates. Examination of the influence of the material on modified and unmodified plates was also achieved using the collected medium. In cultures carried out on modified plates, comparing the number of cells in the collected medium on days 3 , 6 , and 9, statistically significantly higher proliferation was observed in cultures with chitin scaffold, compared to control cultures without it (Figure 12).

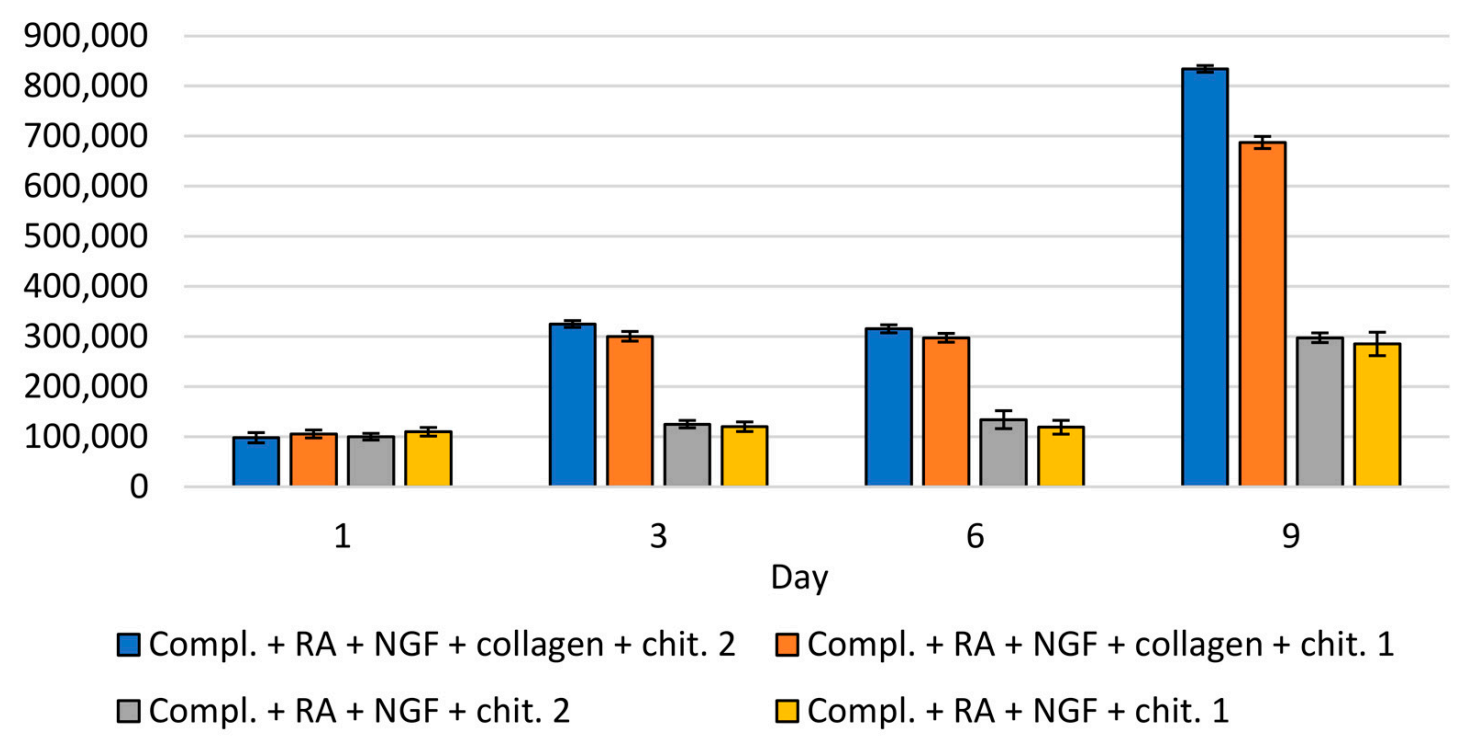

Figure 12. Number of cells SH-SY5Y on chitin scaffold. 
The number of cells in the collected medium was also compared in terms of the method of plating cells onto chitin scaffold. On days 3, 6, and 9, a statistically significant difference was observed in the number of cells in the collected medium between cases. SH-SY5Y cells were seeded directly onto the material, and when the material was placed on the surface of the medium with cells. Interestingly, when the chitin scaffold was placed on the surface of the medium with cells on plates modified with collagen, the cell proliferation was greater than on unmodified plates (Figure 12). A similar effect was observed when SH-SY5Y cells were seeded directly onto the chitin scaffold and when the surface of plates was modified with collagen type I. The highest increase in the proliferation between the first day of culturing and the third, sixth, and ninth was observed when wells were modified with collagen, and the chitin scaffold was placed on the surface of medium with cells. This led to the conclusion that the chitin scaffold increased the proliferation of SH-SY5Y cells.

During the evaluation SH-SY5Y, a greater increase in migration of SH-SY5Y cells to the surface of chitin was observed than to the surface of the wells (regardless of whether modified or unmodified). In cultures carried out on a surface modified with collagen and with chitin scaffold immersed into the medium, a much larger number of cells was recorded on the surface of scaffold than on the surface of the well, on 9th day: scaffoldaverage 1900 cells, surface of well modified with collagen-300-500 cells (data not shown). However, in SH-SY5Y cell cultures grown on the modified surface without scaffold, the number of adherent cells was 800-1000 in the field of view. The above results suggest a higher migration of cells to chitin scaffold than to the surface modified with collagen type I (for more details see Supplementary Materials).

Evaluation of the cell number on the chitin scaffold.

A statistically significant increase in the number of cells on the chitin scaffold between all subsequent days of the study was observed regardless of the application method and the surface of the culture plates (modified or unmodified) (Figure 13).

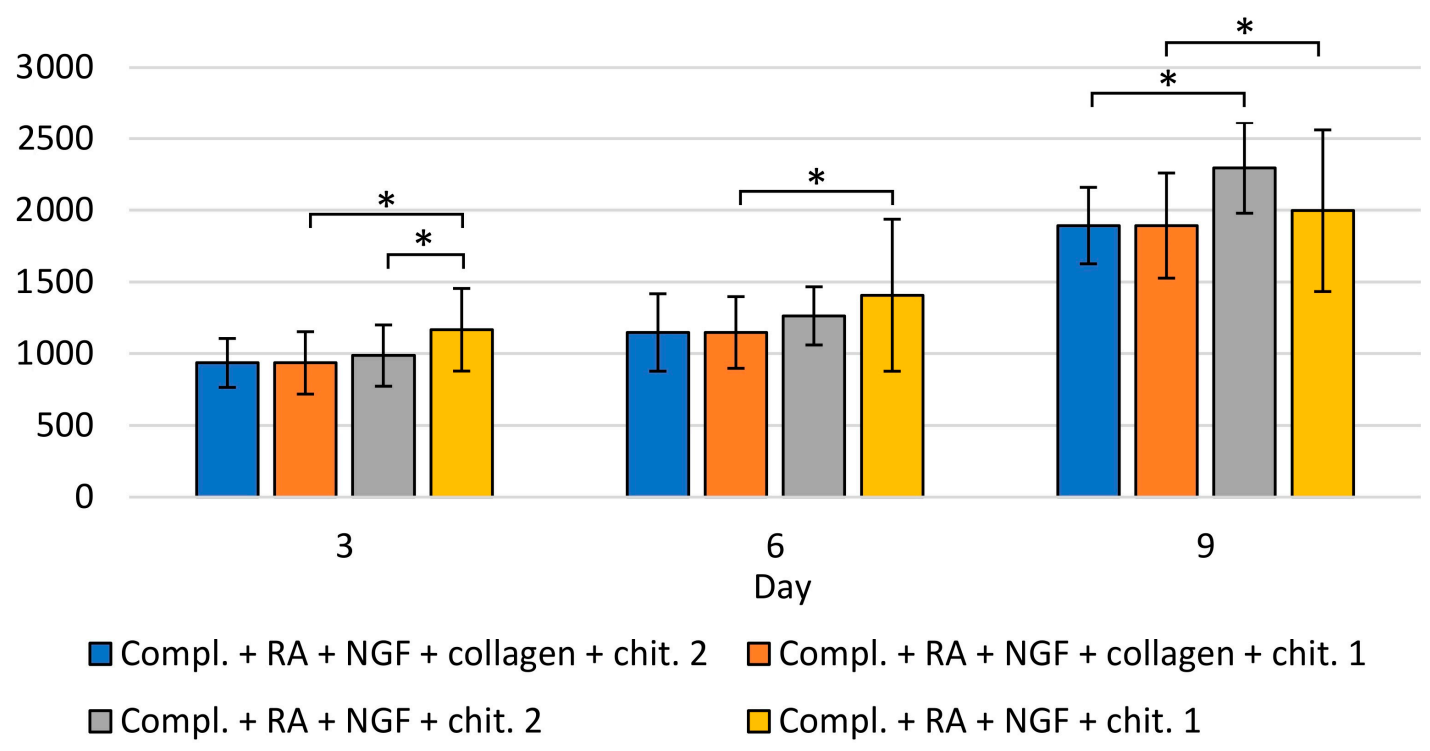

Figure 13. Average number of cells in the field of vision on the microphotographs of chitin scaffold. Statistically significant differences between tested groups: ${ }^{*} p<0.05$.

The effect of covering the surface of culture plate wells on the number of cells was examined. When the cells were seeded directly onto scaffold, a significantly higher number of cells on unmodified plates was observed (in days 3, 6 and 9). When material was immersed in the medium with cells, on day 9 , it was observed that the number of cells was also higher on unmodified plates. The influence of the material application method was also analyzed. On day 3, there was a significant difference on unmodified plates, depending on the scaffold application method-the number of cells was higher when 
the cells were seeded directly onto material. On the 6th and 9th day of breeding, no difference was observed, which may indicate that the cells were migrating to the surface of the material. Moreover, there was a noticeably lower number of cells (without statistical significance) on the 9th day on unmodified plates that showed directly on the material (compared to placing the material on the surface of the medium with cells), suggesting that cell differentiation was taking place. There were no statistically significant differences depending on the scaffold application method in the number of SH-SY5Y cells on the chitin scaffold on collagen-modified plates.

Herein, the poriferan chitinous scaffold from $A$. fistularis has been used as a support for the cultivation of major groups of cells taking part in wound healing (keratinocytes and fibroblasts) and neuronal cells. As described above, our study has proven that the chitinous scaffold of marine demosponge origin has no cytotoxic properties, which is in general a desirable feature for materials used in tissue engineering and all biomaterials. The second feature of great importance for a material dedicated to tissue regeneration is its adhesive properties, which enable the cells to cover the surface, and are also crucial for the application of the material in tissue engineering. Our results, obtained with numerous microscopic techniques, show that the murine fibroblast line Balb/3T3, human dermal fibroblas ts (NHDF), human keratinocyte (HaCaT), and mostly human neuronal (SH-SY5Y) cells can adhere and proliferate on the surface of chitin scaffolds. Previously, several time authors proved that chitin-based scaffolds are a promising material for tissue engineering [23,68-72]. In particular, our observations using the TEM technique show that human keratinocytes form clusters on the scaffold, which resemble the cohesive sheets of cells in the stratified epithelium of the skin and could confirm cell adhesion. The cells strongly adhered to the chitin scaffolds and they keep their normal morphology during tissue processing for TEM, although this procedure includes multiply steps. Moreover, inside this cohesive sheet, the keratinocytes were connected to each other by the desmosomes. Desmosomes play a very important function during morphogenesis and differentiation, and a crucial role during cell adhesion [73]. Because no cell swelling or shrinkage was observed, it excluded the loss of adhesion between the cells. These results indicate that poriferan chitin may be potentially useful in skin tissue regeneration. Fibroblasts and keratinocytes are two major groups of cells that take part in wound healing $[42,67,74]$. This process requires several phases: hemostasis, formation of a fibrin clot, inflammation/granulation, re-epithelialization, and tissue remodeling. In such conditions as venous leg ulcer, diabetic foot, or extensive skin loss, the process of healing can be disrupted and lead to abnormal wound healing $[75,76]$. The identification of suitable scaffolds on which keratinocytes and fibroblast cells can be seeded to generate functional tissues is an important research goal. Our observations are consistent with the work presented by Noh et al., who seeded normal human keratinocytes and fibroblasts on a chitin-based nanofiber scaffold [69]. An additional preliminary study with neuronal cells (SH-SY5Y) confirmed the adhesion and migration of these cells on the scaffold surface, showing that this material is potentially useful in the field of neuronal regeneration. However, further studies may be carried out to determine the cell adhesion rates in these bioscaffolds, as well as the incubation of cells on the scaffold for an extended time to obtain 3D cell cultures which could be used in structure-based tissue engineering [77]. Nevertheless, functionalization of chitinous scaffold surface is required for improving protein and cell attachment.

\section{Conclusions}

Three-dimensional (3D) cell cultures are essential for bulk cell manufacturing and structure-based tissue engineering. However, their arrangement and preparation are still a challenge due to the lack of a highly biocompatible culture environment for several cell types. Herein, for the first time, chitin-based scaffold obtained from the skeleton of the Verongida sponge Aplysina fistularis has been used as a support for the cultivation of murine fibroblasts (Balb/3T3), human dermal fibroblasts (NHDF), human keratinocyte (HaCaT), and human neuronal (SH-SY5Y) cells. Characterization techniques, such as ATR 
FTIR, TGA, and $\mu \mathrm{CT}$, clearly indicate that an interconnected macro-porous, thermostable, pure $\alpha$-chitin scaffold is obtained after alkali-acid treatment of air-dried marine sponge. DMA mechanical testing shows that the chitinous scaffold of poriferan origin exhibits soft mechanical properties like those of a natural extracellular matrix. Nevertheless, future functionalization of scaffold surface is required to improve cell attachment and spreading. The non-cytotoxicity of such a construct is confirmed by a lack of morphological changes in Balb/3T3 cells after $24 \mathrm{~h}$ of incubation. Moreover, various staining techniques (Neutral Red, Crystal Violet) and microscopic observations confirmed cell adhesion and proliferation in a 7-day culture. The TEM technique was used for determining the ultrastructure of fibroblasts and keratinocytes cultivated on a chitinous scaffold of marine sponge origin. As observed, keratinocytes form clusters on the scaffold which resemble a skin structure, including the occurrence of desmosomes linking these cells in the cohesive sheet. Our preliminary results show the good proliferation of neuronal cells on the soft chitinous scaffold. This article also describes that cultures of neuronal cells are more likely to migrate to the 3D chitin scaffold than to the surface of type I collagen. Thus, in this study, we reported that three-dimensional chitinous scaffolds are beneficial as they provide a nontoxic, biomimetic environment for various cell types. The use of their naturally formed structure is costeffective because no additional manufacturing techniques are required for the preparation of centimeter-sized scaffolds.

Supplementary Materials: The following are available online at https:/ / www.mdpi.com/article/10

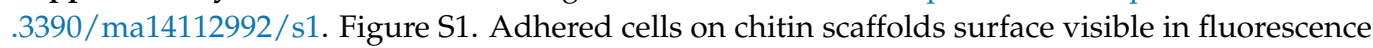
with Neutral Red staining after incubation (A-C) for $24 \mathrm{~h}$ and (D-F) for 7 days. (A,D)-Balb/3T3; (B,E)-NHDF; (C,F)—HaCaT. Figure S2. Adhered cells on chitin scaffolds surface visualized with Neutral Red staining (A-C) after incubation for $24 \mathrm{~h}$ and (D-F) for 7 days (D-F). (A,D)-Balb/3T3; (B,E)-NHDF; (C,F)-HaCaT. Figure S3. SEM images of pure chitinous scaffold surface. Figure S4. Representative electron microphotographs of NHDF cell morphology. Nuclei without signs of death are conspicuous and the well-preserved ultrastructure of organelles is visible. $\mathrm{N}$-nucleus, $\mathrm{Nu}$-reticular nucleolus, $\mathrm{Mb}$-multivesicular body, RER-rough endoplasmic reticulum, black arrows—mitochondria, red arrows—Golgi apparatus. Magnification: A-12,000×; B-10,000×;C and D-30,000 $\times$. Figure S5. Number of cells in the collected medium (cell cultures without chitin material). Statistically significant differences between tested groups: ${ }^{*} p<0.05$.

Author Contributions: Conceptualization, T.J., T.M. and A.R.; methodology, T.M., A.R., B.W., K.H.-L. and A.Ż.; validation, A.P., T.M. and T.J.; investigation, A.P., A.R., T.M. and B.W.; resources, T.M.; data curation, T.M., A.R., A.P., M.P.-O. and T.J.; writing—original draft preparation, T.M., A.R., A.P., B.W. and T.J.; writing-review and editing, T.J.; visualization, A.Ż., A.R., T.M., K.H.-L. and J.J.; supervision, M.P.-O. and T.J.; funding acquisition, M.P.-O. and T.J. All authors have read and agreed to the published version of the manuscript.

Funding: This work was partially supported by the Ministry of Science and Higher Education (Poland).

Institutional Review Board Statement: Not applicable.

Informed Consent Statement: Not applicable.

Data Availability Statement: Data is contained within the article and supplementary material.

Acknowledgments: The authors would like to give special thanks to Magdalena Baran-Pelc for the excellent technical support in transmission electron microscopy, and Marcin Heljak for DMA analysis. Moreover, special thanks are given to INTIB GmbH (Germany) for the supply of sponge specimens and Hermann Ehrlich for valuable comments.

Conflicts of Interest: The authors declare no conflict of interest. The funders had no role in the design of the study; in the collection, analyses, or interpretation of data; in the writing of the manuscript, or in the decision to publish the results. 


\section{References}

1. Nikolova, M.P.; Chavali, M.S. Recent advances in biomaterials for 3D scaffolds: A review. Bioact. Mater. 2019, 4, 271-292. [CrossRef]

2. Pina, S.; Ribeiro, V.P.; Marques, C.F.; Maia, F.R.; Silva, T.H.; Reis, R.L.; Oliveira, J.M. Scaffolding Strategies for Tissue Engineering and Regenerative Medicine Applications. Materials 2019, 12, 1824. [CrossRef]

3. Baldino, L.; Cardea, S.; Scognamiglio, M.; Reverchon, E. A new tool to produce alginate-based aerogels for medical applications, by supercritical gel drying. J. Supercrit. Fluids 2019, 146, 152-158. [CrossRef]

4. Binnewerg, B.; Schubert, M.; Voronkina, A.; Muzychka, L.; Wysokowski, M.; Petrenko, I.; Djurović, M.; Kovalchuk, V.; Tsurkan, M.; Martinovic, R.; et al. Marine biomaterials: Biomimetic and pharmacological potential of cultivated Aplysina aerophoba marine demosponge. Mater. Sci. Eng. C 2020, 109, 110566. [CrossRef]

5. Machałowski, T.; Amemiya, C.; Jesionowski, T. Chitin of Araneae origin: Structural features and biomimetic applications: A review. Appl. Phys. A 2020, 126,1-17. [CrossRef]

6. Klinger, C.; Żółtowska-Aksamitowska, S.; Wysokowski, M.; Tsurkan, M.V.; Galli, R.; Petrenko, I.; Machałowski, T.; Ereskovsky, A.; Martinović, R.; Muzychka, L.; et al. Express Method for Isolation of Ready-to-Use 3D Chitin Scaffolds from Aplysina archeri (Aplysineidae: Verongiida) Demosponge. Mar. Drugs 2019, 17, 131. [CrossRef]

7. Wysokowski, M.; Machałowski, T.; Petrenko, I.; Schimpf, C.; Rafaja, D.; Galli, R.; Ziętek, J.; Pantović, S.; Voronkina, A.; Kovalchuk, V.; et al. 3D Chitin Scaffolds of Marine Demosponge Origin for Biomimetic Mollusk Hemolymph-Associated Biomineralization Ex-Vivo. Mar. Drugs 2020, 18, 123. [CrossRef]

8. Jones, M.; Kujundzic, M.; John, S.; Bismarck, A. Crab vs. Mushroom: A Review of Crustacean and Fungal Chitin in Wound Treatment. Mar. Drugs 2020, 18, 64. [CrossRef]

9. Mutsenko, V.V.; Gryshkov, O.; Lauterboeck, L.; Rogulska, O.; Tarusin, D.N.; Bazhenov, V.; Schütz, K.; Brüggemeier, S.; Gossla, E.; Akkineni, A.R.; et al. Novel chitin scaffolds derived from marine sponge Ianthella basta for tissue engineering approaches based on human mesenchymal stromal cells: Biocompatibility and cryopreservation. Int. J. Biol. Macromol. 2017, 104, 1955-1965. [CrossRef]

10. Chen, B.; Wu, S.; Ye, Q. Fabrication and characterization of biodegradable KH560 crosslinked chitin hydrogels with high toughness and good biocompatibility. Carbohydr. Polym. 2021, 259, 117707. [CrossRef]

11. Barzic, I.A.; Albu, R.M. Optical properties and biointerface interactions of chitin. Polym. Bull. 2020. [CrossRef]

12. Bacakova, L.; Filova, E.; Parizek, M.; Ruml, T.; Svorcik, V. Modulation of cell adhesion, proliferation and differentiation on materials designed for body implants. Biotechnol. Adv. 2011, 29, 739-767. [CrossRef] [PubMed]

13. Jaworska, M.M.; Gorak, A. Modification of chitin particles with chloride ionic liquids. Mater. Lett. 2016, 164, 341-343. [CrossRef]

14. Duan, B.; Liu, F.; He, M.; Zhang, L. Ag- $\mathrm{Fe}_{3} \mathrm{O}_{4}$ nanocomposites@chitin microspheres constructed by in situ one-pot synthesis for rapid hydrogenation catalysis. Green Chem. 2014, 16, 2835-2845. [CrossRef]

15. Rodríguez-Vázquez, M.; Vega-Ruiz, B.; Ramos-Zúñiga, R.; Saldaña-Koppel, D.A.; Quiñones-Olvera, L.F. Chitosan and its potential use as a scaffold for tissue engineering in regenerative medicine. Biomed Res. Int. 2015, 2015, 821279. [CrossRef]

16. Kosik-Kozioł, A.; Costantini, M.; Mróz, A.; Idaszek, J.; Heljak, M.; Jaroszewicz, J.; Kijeńska, E.; Szöke, K.; Frerker, N.; Barbetta, A.; et al. 3D bioprinted hydrogel model incorporating $\beta$-tricalcium phosphate for calcified cartilage tissue engineering. Biofabrication 2019, 11, 035016. [CrossRef]

17. Walejewska, E.; Idaszek, J.; Heljak, M.; Chlanda, A.; Choinska, E.; Hasirci, V.; Swieszkowski, W. The effect of introduction of filament shift on degradation behaviour of PLGA- and PLCL-based scaffolds fabricated via additive manufacturing. Polym. Degrad. Stab. 2020, 171, 109030. [CrossRef]

18. Jaroszewicz, J.; Idaszek, J.; Choinska, E.; Szlazak, K.; Hyc, A.; Osiecka-Iwan, A.; Swieszkowski, W.; Moskalewski, S. Formation of calcium phosphate coatings within polycaprolactone scaffolds by simple, alkaline phosphatase based method. Mater. Sci. Eng. C 2019, 96, 319-328. [CrossRef]

19. Idaszek, J.; Kijeńska, E.; Łojkowski, M.; Swieszkowski, W. How important are scaffolds and their surface properties in regenerative medicine. Appl. Surf. Sci. 2016, 388, 762-774. [CrossRef]

20. Dušková-Smrčková, M.; Zavřel, J.; Bartoš, M.; Kaberova, Z.; Filová, E.; Zárubová, J.; Šlouf, M.; Michálek, J.; Vampola, T.; Kubies, D. Communicating macropores in PHEMA-based hydrogels for cell seeding: Probabilistic open pore simulation and direct micro-CT proof. Mater. Des. 2021, 198, 109312. [CrossRef]

21. Janoušková, O.; Přádný, M.; Vetrík, M.; Krumbholcová, E.C.; Michálek, J.; Smrčková, M.D. Biomimetic modification of dual porosity poly(2-hydroxyethyl methacrylate) hydrogel scaffolds-porosity and stem cell growth evaluation. Biomed. Mater. 2019, 14, 055004. [CrossRef]

22. Přádný, M.; Dušková-Smrčková, M.; Dušek, K.; Janoušková, O.; Sadakbayeva, Z.; Šlouf, M.; Michálek, J. Macroporous 2hydroxyethyl methacrylate hydrogels of dual porosity for cell cultivation: Morphology, swelling, permeability, and mechanical behavior. J. Polym. Res. 2014, 21, 579. [CrossRef]

23. Park, K.E.; Kang, H.K.; Lee, S.J.; Min, B.-M.; Park, W.H. Biomimetic Nanofibrous Scaffolds: Preparation and Characterization of PGA/Chitin Blend Nanofibers. Biomacromolecules 2006, 7, 635-643. [CrossRef]

24. Litowczenko, J.; Woźniak-Budych, M.J.; Staszak, K.; Wieszczycka, K.; Jurga, S.; Tylkowski, B. Milestones and current achievements in development of multifunctional bioscaffolds for medical application. Bioact. Mater. 2021, 6, 2412-2438. [CrossRef] 
25. Gilbert, T.W.; Sellaro, T.L.; Badylak, S.F. Decellularization of tissues and organs. Biomaterials 2006, 27, 3675-3683. [CrossRef] [PubMed]

26. Costa, A.; Naranjo, J.D.; Londono, R.; Badylak, S.F. Biologic Scaffolds. Cold Spring Harb. Perspect. Med. 2017, 7, a025676. [CrossRef]

27. Smith, C.A.; Board, T.N.; Rooney, P.; Eagle, M.J.; Richardson, M.; Hoyland, J.A. Human decellularized bone scaffolds from aged donors show improved osteoinductive capacity compared to young donor bone. PLoS ONE 2017, 12, e0177416. [CrossRef]

28. Tsurkan, D.; Wysokowski, M.; Petrenko, I.; Voronkina, A.; Khrunyk, Y.; Fursov, A.; Ehrlich, H. Modern scaffolding strategies based on naturally pre-fabricated 3D biomaterials of poriferan origin. Appl. Phys. A 2020, 126, 1-9. [CrossRef]

29. Petrenko, I.; Khrunyk, Y.; Voronkina, A.; Kovalchuk, V.; Fursov, A.; Tsurkan, D.; Ivanenko, V. Poriferan chitin: 3D scaffolds from nano- to macroscale. A review. Lett. Appl. Nanobiosci. 2020, 9, 1004-1014.

30. Negrini, N.C.; Toffoletto, N.; Farè, S.; Altomare, L. Plant Tissues as 3D Natural Scaffolds for Adipose, Bone and Tendon Tissue Regeneration. Front. Bioeng. Biotechnol. 2020, 8, 723. [CrossRef]

31. Nowacki, K.; Stẹpniak, I.; Machalowski, T.; Wysokowski, M.; Petrenko, I.; Schimpf, C.; Rafaja, D.; Ziętek, J.; Pantović, S.; Voronkina, A.; et al. Electrochemical method for isolation of chitinous 3D scaffolds from cultivated Aplysina aerophoba marine demosponge and its biomimetic application. Appl. Phys. A 2020, 126, 368. [CrossRef]

32. García-Vilas, J.A.; Martínez-Poveda, B.; Quesada, A.R.; Medina, M.Á. Aeroplysinin-1, a sponge-serived multi-targeted bioactive marine drug. Mar. Drugs 2016, 14, 1. [CrossRef]

33. Bechmann, N.; Ehrlich, H.; Eisenhofer, G.; Ehrlich, A.; Meschke, S.; Ziegler, C.G.; Bornstein, S.R. Anti-Tumorigenic and AntiMetastatic Activity of the Sponge-Derived Marine Drugs Aeroplysinin-1 and Isofistularin-3 against Pheochromocytoma In Vitro. Mar. Drugs 2018, 16, 172. [CrossRef]

34. Schubert, M.; Binnewerg, B.; Voronkina, A.; Muzychka, L.; Wysokowski, M.; Petrenko, I.; Kovalchuk, V.; Tsurkan, M.; Martinovic, R.; Bechmann, N.; et al. Naturally Prefabricated Marine Biomaterials: Isolation and Applications of Flat Chitinous 3D Scaffolds from Ianthella labyrinthus (Demospongiae: Verongiida). Int. J. Mol. Sci. 2019, 20, 5105. [CrossRef]

35. Machałowski, T.; Czajka, M.; Petrenko, I.; Meissner, H.; Schimpf, C.; Rafaja, D.; Ziętek, J.; Dzięgiel, B.; Adaszek, Ł.; Voronkina, A.; et al. Functionalization of 3D Chitinous Skeletal Scaffolds of Sponge Origin Using Silver Nanoparticles and Their Antibacterial Properties. Mar. Drugs 2020, 18, 304. [CrossRef]

36. Wysokowski, M.; Motylenko, M.; Bazhenov, V.V.; Stawski, D.; Petrenko, I.; Ehrlich, A.; Behm, T.; Kljajic, Z.; Stelling, A.L.; Jesionowski, T.; et al. Poriferan chitin as a template for hydrothermal zirconia deposition. Front. Mater. Sci. 2013, 7, 248-260. [CrossRef]

37. Zdarta, J.; Machałowski, T.; Degórska, O.; Bachosz, K.; Fursov, A.; Ehrlich, H.; Ivanenko, V.N.; Jesionowski, T. 3D Chitin Scaffolds from the Marine Demosponge Aplysina archeri as a Support for Laccase Immobilization and Its Use in the Removal of Pharmaceuticals. Biomolecules 2020, 10, 646. [CrossRef]

38. Wysokowski, M.; Petrenko, I.; Stelling, A.L.; Stawski, D.; Jesionowski, T.; Ehrlich, H. Poriferan Chitin as a Versatile Template for Extreme Biomimetics. Polymers 2015, 7, 235-265. [CrossRef]

39. Ehrlich, H.; Krautter, M.; Hanke, T.; Simon, P.; Knieb, C.; Heinemann, S.; Worch, H. First evidence of the presence of chitin in skeletons of marine sponges. Part II. Glass sponges (Hexactinellida: Porifera). J. Exp. Zoöl. Part B Mol. Dev. Evol. 2007, 308B, 473-483. [CrossRef]

40. Mutsenko, V.V.; Bazhenov, V.; Rogulska, O.; Tarusin, D.N.; Schütz, K.; Brüggemeier, S.; Gossla, E.; Akkineni, A.R.; Meißner, H.; Lode, A.; et al. 3D chitinous scaffolds derived from cultivated marine demosponge Aplysina aerophoba for tissue engineering approaches based on human mesenchymal stromal cells. Int. J. Biol. Macromol. 2017, 104, 1966-1974. [CrossRef]

41. Rogulska, O.Y.; Mutsenko, V.V.; Revenko, E.B.; Petrenko, Y.A.; Ehrlich, H.; Petrenko, A.Y. Culture and differentiation of human adipose tissue mesenchymal stromal cells within carriers based on sea sponge chitin skeletons. Probl. Cryobiol. Cryomed. 2013, 23, 267-270.

42. Mutsenko, V.V.; Rogulska, O.Y.; Petrenko, Y.A.; Ehrlich, H.; Mazur, S.P.; Volkova, N.A.; Petrenko, A.Y. Cryosensitivity of Mesenchymal Stromal Cells Cryopreserved Within Marine Sponge Ianthella basta Skeleton-Based Carriers. Probl. Cryobiol. Cryomed. 2016, 26, 13-23. [CrossRef]

43. Machałowski, T.; Wysokowski, M.; Tsurkan, M.V.; Galli, R.; Schimpf, C.; Rafaja, D.; Brendler, E.; Viehweger, C.; ŻółtowskaAksamitowska, S.; Petrenko, I.; et al. Spider Chitin: An Ultrafast Microwave-Assisted Method for Chitin Isolation from Caribena versicolor Spider Molt Cuticle. Molecules 2019, 24, 3736. [CrossRef]

44. Gbenebor, O.; Adeosun, S.; Lawal, G.; Jun, S.; Olaleye, S. Acetylation, crystalline and morphological properties of structural polysaccharide from shrimp exoskeleton. Eng. Sci. Technol. Int. J. 2017, 20, 1155-1165. [CrossRef]

45. Knidri, H.E.; Khalfaouy, R.E.; Laajeb, A.; Addaou, A.; Lahsini, A. Eco-friendly extraction and characterization of chitin and chitosan from the shrimp shell waste via microwave irradiation. Process. Saf. Environ. Prot. 2016, 104, 395-405. [CrossRef]

46. Heljak, M.K.; Moczulska-Heljak, M.; Choińska, E.; Chlanda, A.; Kosik-Kozioł, A.; Jaroszewicz, T.; Jaroszewicz, J.; Swieszkowski, W. Micro and nanoscale characterization of poly(DL-lactic-co-glycolic acid) films subjected to the L929 cells and the cyclic mechanical load. Micron 2018, 115, 64-72. [CrossRef]

47. Hildebrand, T.; Rüegsegger, P. A new method for the model-independent assessment of thickness in three-dimensional images. J. Microsc. 1997, 185, 67-75. [CrossRef]

48. Boukamp, P.; Petrussevska, R.T.; Breitkreutz, D.; Hornung, J.; Markham, A.; Fusenig, N.E. Normal keratinization in a spontaneously immortalized aneuploid human keratinocyte cell line. J. Cell Biol. 1988, 106, 761-771. [CrossRef] 
49. Nawrotek, K.; Marqueste, T.; Modrzejewska, Z.; Zarzycki, R.; Rusak, A.; Decherchi, P. Thermogelling chitosan lactate hydrogel improves functional recovery after a C2 spinal cord hemisection in rat. J. Biomed. Mater. Res. Part A 2017, 105, 2004-2019. [CrossRef]

50. Tomanik, M.; Kobielarz, M.; Filipiak, J.; Szymonowicz, M.; Rusak, A.; Mroczkowska, K.; Antończak, A.; Pezowicz, C. Laser Texturing as a Way of Influencing the Micromechanical and Biological Properties of the Poly(L-Lactide) Surface. Materials 2020, 13, 3786. [CrossRef]

51. Fernández-Cervantes, I.; Rodríguez-Fuentes, N.; León-Deniz, L.V.; Quintana, L.E.A.; Cervantes-Uc, J.M.; Kao, W.A.H.; CerónEspinosa, J.D.; Cauich-Rodríguez, J.V.; Castaño-Meneses, V.M. Cell-free scaffold from jellyfish Cassiopea andromeda (Cnidaria; Scyphozoa) for skin tissue engineering. Mater. Sci. Eng. C 2020, 111, 110748. [CrossRef]

52. Borenfreund, E.; Puerner, J.A. Toxicity determined in vitro by morphological alterations and neutral red absorption. Toxicol. Lett. 1985, 24, 119-124. [CrossRef]

53. Wysokowski, M.; Bazhenov, V.V.; Tsurkan, M.V.; Galli, R.; Stelling, A.L.; Stöcker, H.; Kaiser, S.; Niederschlag, E.; Gärtner, G.; Behm, T.; et al. Isolation and identification of chitin in three-dimensional skeleton of Aplysina fistularis marine sponge. Int. J. Biol. Macromol. 2013, 62, 94-100. [CrossRef]

54. Chatelet, C.; Damour, O.; Domard, A. Influence of the degree of acetylation on some biological properties of chitosan films. Biomaterials 2001, 22, 261-268. [CrossRef]

55. Brunner, E.; Ehrlich, H.; Schupp, P.; Hedrich, R.; Hunoldt, S.; Kammer, M.; Machill, S.; Paasch, S.; Bazhenov, V.; Kurek, D.; et al. Chitin-based scaffolds are an integral part of the skeleton of the marine demosponge Ianthella basta. J. Struct. Biol. 2009, 168, 539-547. [CrossRef]

56. Kaya, M.; Mujtaba, M.; Ehrlich, H.; Salaberria, A.M.; Baran, T.; Amemiya, C.T.; Galli, R.; Akyuz, L.; Sargin, I.; Labidi, J. On chemistry of $\gamma$-chitin. Carbohydr. Polym. 2017, 176, 177-186. [CrossRef]

57. Kumirska, J.; Czerwicka, M.; Kaczyński, Z.; Bychowska, A.; Brzozowski, K.; Thöming, J.; Stepnowski, P. Application of Spectroscopic Methods for Structural Analysis of Chitin and Chitosan. Mar. Drugs 2010, 8, 1567-1636. [CrossRef]

58. Szatkowski, T.; Kołodziejczak-Radzimska, A.; Zdarta, J.; Szwarc-Rzepka, K.; Paukszta, D.; Wysokowski, M.; Ehrlich, H.; Jesionowski, T. Synthesis and characterization of hydroxyapatite/chitosan composites. Physicochem. Probl. Miner. Process. 2015, $51,575-585$.

59. Liu, J.; Zheng, H.; Poh, P.S.P.; Machens, H.-G.; Schilling, A.F. Hydrogels for Engineering of Perfusable Vascular Networks. Int. J. Mol. Sci. 2015, 16, 15997-16016. [CrossRef]

60. Cox, T.R.; Erler, J.T. Remodeling and homeostasis of the extracellular matrix: Implications for fibrotic diseases and cancer. Dis. Model. Mech. 2011, 4, 165-178. [CrossRef]

61. Breuls, R.G.; Jiya, T.U.; Smit, T.H. Scaffold Stiffness Influences Cell Behavior: Opportunities for Skeletal Tissue Engineering. Open Orthop. J. 2008, 2, 103-109. [CrossRef]

62. Intini, C.; Elviri, L.; Cabral, J.; Mros, S.; Bergonzi, C.; Bianchera, A.; Flammini, L.; Govoni, P.; Barocelli, E.; Bettini, R.; et al. 3D-printed chitosan-based scaffolds: An in vitro study of human skin cell growth and an in-vivo wound healing evaluation in experimental diabetes in rats. Carbohydr. Polym. 2018, 199, 593-602. [CrossRef]

63. Black, L.D.; Allen, P.G.; Morris, S.M.; Stone, P.J.; Suki, B. Mechanical and Failure Properties of Extracellular Matrix Sheets as a Function of Structural Protein Composition. Biophys. J. 2008, 94, 1916-1929. [CrossRef]

64. Mei, N.; Chen, G.; Zhou, P.; Chen, X.; Shao, Z.-Z.; Pan, L.-F.; Wu, C.-G. Biocompatibility of Poly(e-caprolactone) scaffold modified by chitosan-The fibroblasts proliferation in vitro. J. Biomater. Appl. 2005, 19, 323-339. [CrossRef]

65. Tinari, A.; Giammarioli, A.M.; Manganelli, V.; Ciarlo, L.; Malorni, W. Analyzing morphological and ultrastructural features in cell death. In Methods in Enzymology; Khosravi-Far, R., Zakeri, Z., Lockshin, R.A., Piacentini, M., Eds.; Elsevier: Amsterdam, The Netherlands, 2008; Volume 442, pp. 1-26. ISBN 9780123743121.

66. Ulivieri, C. Cell death: Insights into the ultrastructure of mitochondria. Tissue Cell 2010, 42, 339-347. [CrossRef]

67. Piipponen, M.; Li, D.; Landén, N.X. The Immune Functions of Keratinocytes in Skin Wound Healing. Int. J. Mol. Sci. 2020, 21, 8790. [CrossRef]

68. Mutsenko, V.; Gryshkov, O.; Rogulska, O.; Lode, A.; Petrenko, A.Y.; Gelinsky, M.; Glasmacher, B.; Ehrlich, H. Chitinous scaffolds from marine sponges for tissue engineering. In Marine-Derived Biomaterials for Tissue Engineering Applications Chitinous; Choi, A., Ben-Nissan, B., Eds.; Springer Nature: Singapore, 2019; pp. 285-307.

69. Noh, H.K.; Lee, S.W.; Kim, J.-M.; Oh, J.-E.; Kim, K.-H.; Chung, C.-P.; Choi, S.-C.; Park, W.H.; Min, B.-M. Electrospinning of chitin nanofibers: Degradation behavior and cellular response to normal human keratinocytes and fibroblasts. Biomaterials 2006, 27, 3934-3944. [CrossRef]

70. Jayakumar, R.; Prabaharan, M.; Kumar, P.S.; Nair, S.; Tamura, H. Biomaterials based on chitin and chitosan in wound dressing applications. Biotechnol. Adv. 2011, 29, 322-337. [CrossRef]

71. Jayakumar, R.; Chennazhi, K.P.; Srinivasan, S.; Nair, S.V.; Furuike, T.; Tamura, H. Chitin Scaffolds in Tissue Engineering. Int. J. Mol. Sci. 2011, 12, 1876-1887. [CrossRef] [PubMed]

72. Park, K.E.; Jung, S.Y.; Lee, S.J.; Min, B.-M.; Park, W.H. Biomimetic nanofibrous scaffolds: Preparation and characterization of chitin/silk fibroin blend nanofibers. Int. J. Biol. Macromol. 2006, 38, 165-173. [CrossRef]

73. Johnson, J.L.; Najor, N.A.; Green, K.J. Desmosomes: Regulators of Cellular Signaling and Adhesion in Epidermal Health and Disease. Cold Spring Harb. Perspect. Med. 2014, 4, a015297. [CrossRef] 
74. Uluer, E.T.; Vatansever, H.S.; Aydede, H.; Ozbilgin, M.K. Keratinocytes derived from embryonic stem cells induce wound healing in mice. Biotech. Histochem. 2019, 94, 189-198. [CrossRef]

75. Sorg, H.; Tilkorn, D.J.; Hager, S.; Hauser, J.; Mirastschijski, U. Skin Wound Healing: An update on the Current Knowledge and Concepts. Eur. Surg. Res. 2017, 58, 81-94. [CrossRef]

76. Wojtowicz, A.M.; Oliveira, S.; Carlson, M.W.; Zawadzka, A.; Rousseau, C.F.; Baksh, D. The importance of both fibroblasts and keratinocytes in a bilayered living cellular construct used in wound healing. Wound Repair Regen. 2014, 22, 246-255. [CrossRef]

77. Su, X.; Tan, M.; Duan, B.; Cai, J.; Jiang, W.; Zhang, L. Hierarchical microspheres with macropores fabricated from chitin as 3D cell culture. J. Mater. Chem. B 2019, 7, 5190-5198. [CrossRef] [PubMed] 